NBER WORKING PAPER SERIES

FINANCIAL LITERACY, SCHOOLING, AND WEALTH ACCUMULATION

Jere R. Behrman

Olivia S. Mitchell

Cindy Soo

David Bravo

Working Paper 16452

http://www.nber.org/papers/w16452

\author{
NATIONAL BUREAU OF ECONOMIC RESEARCH \\ 1050 Massachusetts Avenue \\ Cambridge, MA 02138 \\ October 2010
}

This paper is part of the NBER's Research Program on the Economics of Aging. The authors acknowledge support provided by the TIAA-CREF Institute, the Pension Research Council and Boettner Center at the Wharton School of the University of Pennsylvania, and NIH/NIA grant AG023774-01(P.I. Petra Todd) on "Lifecycle health, work, aging, insurance and pensions in Chile." They also thank Luc Arrondel, Alex Gelber, Jeremy Tobacman, Javiera Vasquez, and participants in the Wharton Applied Economics doctoral workshop as well as the 2010 LBS TransAtlantic Doctoral Conference for helpful comments, and Richard Derrig for sharing his PRIDIT code. Opinions and errors are solely those of the authors and not of the institutions providing funding for this study or with which the authors are affiliated. (O2010 Behrman, Mitchell, Soo, and Bravo. All rights reserved. The views expressed herein are those of the authors and do not necessarily reflect the views of the National Bureau of Economic Research.

NBER working papers are circulated for discussion and comment purposes. They have not been peerreviewed or been subject to the review by the NBER Board of Directors that accompanies official NBER publications.

(C) 2010 by Jere R. Behrman, Olivia S. Mitchell, Cindy Soo, and David Bravo. All rights reserved. Short sections of text, not to exceed two paragraphs, may be quoted without explicit permission provided that full credit, including $\odot$ notice, is given to the source. 
Financial Literacy, Schooling, and Wealth Accumulation

Jere R. Behrman, Olivia S. Mitchell, Cindy Soo, and David Bravo

NBER Working Paper No. 16452

October 2010

JEL No. G14,G23,I21,I3,J14,J24,J26,J32

\begin{abstract}
$\underline{\text { ABSTRACT }}$
Financial literacy and schooling attainment have been linked to household wealth accumulation. Yet prior findings may be biased due to noisy measures of financial literacy and schooling, as well as unobserved factors such as ability, intelligence, and motivation that could enhance financial literacy and schooling but also directly affect wealth accumulation. We use a new household dataset and an instrumental variables approach to isolate the causal effects of financial literacy and schooling on wealth accumulation. While financial literacy and schooling attainment are both strongly positively associated with wealth outcomes in linear regression models, our approach reveals even stronger and larger effects of financial literacy on wealth. Estimated impacts are substantial enough to suggest that investments in financial literacy could have large positive effects on household wealth accumulation.
\end{abstract}

Jere R. Behrman

University of Pennsylvania

jbehrman@econ.upenn.edu

Olivia S. Mitchell

University of Pennsylvania

Wharton School

3620 Locust Walk, St 3000 SH-DH

Philadelphia, PA 19104-6302

and NBER

mitchelo@wharton.upenn.edu
Cindy Soo

3620 Locust Walk

St 3000 SHDH

Dept of Insurance \& Risk Management

Wharton School, University of Pennsylvania

csoo@wharton.upenn.edu

David Bravo

Centro de Microdatos

Universidad de Chile

Diag Paraguay \#257, Torre 26

Santiago, Chile

dbravo@econ.facea.uchile.cl 


\title{
Financial Literacy, Schooling, and Wealth Accumulation
}

\author{
Jere R. Behrman, Olivia S. Mitchell, Cindy K. Soo, and David Bravo
}

Traditional economic theory posits that forward-looking individuals maximize expected lifetime utility using economic information to accumulate and then decumulate wealth effectively over their lifetimes. Yet survey evidence reveals that fewer than half of U.S. workers have even attempted to estimate how much money they might need in retirement, and many older adults face significant retirement saving shortfalls (Lusardi and Mitchell 2007a and b; Mitchell and Moore 1998; Scholz, Seshadri, and Khitatrakun 2006). Numerous economic explanations for these phenomena have been suggested including dispersion in discount rates, risk aversion, and credit constraints, but the empirical literature exploring such factors thus far has been unable to account for much of the observed differentials in wealth (Bernheim, Skinner, and Weinberg, 2001; Barsky, Juster, Kimball, and Shapiro, 1997).

The present study seeks to evaluate whether people who find it difficult to understand their financial environment are also less likely to accumulate wealth. Specifically, we examine the links between financial literacy, by which we mean the ability to process economic information and make informed decisions about household finances, and wealth accumulation and pension contributions. Previous studies have reported strong correlations between financial literacy and asset accumulation as well as retirement planning. ${ }^{1}$ These findings have prompted policymakers to support efforts to enhance household wealth accumulation and welfare through increasing financial literacy. For instance, the U.S. President's Advisory Council on Financial Literacy recently stated that (PACFL, 2008, np): "While the crisis has many causes, it is undeniable that financial illiteracy is one of the root causes... Sadly, far too many Americans do not have the basic financial skills necessary to develop and maintain a budget, to understand credit, to understand investment vehicles, or to take advantage of our banking system. It is essential to provide basic financial education that allows people to better navigate an economic crisis such as this one.” Similarly, the Organization for Economic Cooperation and Development

\footnotetext{
${ }^{1}$ For instance, Hilgert, Hogarth, and Beverley (2003) show that more financially knowledgeable US respondents are also more likely to engage in a wide range of recommended financial practices; Lusardi and Mitchell (2007a, b) find that more financially literate elderly U.S. respondents are also more likely to plan, to succeed in planning, and to invest in complex assets; and Campbell (2006) reports that more educated Swedish households also diversify their portfolios more efficiently. Cole, Sampson, and Zia (2009) find that the financially more literate are more likely to have bank accounts in India and Indonesia.
} 
(OECD nd) has recently launched a major initiative to "identify individuals who are most in need of financial education and the best ways to improve that education.”

Despite these and other enthusiastic endorsements for programs to boost financial literacy, questions have been raised about whether these associations reflect causality (Lusardi and Mitchell, 2008, 2010). For example, individuals who fail to save also may be financially illiterate due to some underlying and usually unobservable factor such as impatience, making it difficult to assess whether boosting financial education would, in fact, enhance household wealth accumulation. Moreover, in simple bivariate associations of financial literacy with wealth, financial literacy might be proxying, in part, for other factors such as schooling attainment. Empirical measures of financial literacy are also likely to have considerable measurement error that, ceteris paribus, is likely to bias standard estimates of the impacts of financial literacy towards zero. Instrumental variable (IV) estimates in principle can control for both the unobserved variable and the random measurement error biases, and schooling attainment can be included in the same specification to control for the possibility that financial literacy proxies for schooling. To our knowledge, however, no studies have yet used IV methods to estimate the impact of financial literacy and schooling attainment on wealth, as we do here. ${ }^{2}$

In what follows, we draw on a unique microeconomic dataset, the Chilean Social Protection Survey, to explore how financial literacy and schooling attainment influence wealth. ${ }^{3}$ This dataset includes extensive information on household wealth as well as individual and household characteristics for a representative sample of prime-age adults, permitting us to evaluate the effects of financial literacy using a richer range of ages and schooling than heretofore available. ${ }^{4}$ Using a set of plausibly exogenous instrumental variables that satisfy critical diagnostic tests to isolate the causal effects of financial literacy and schooling attainment

\footnotetext{
${ }^{2}$ Some studies have looked at related issues using IV methods. For instance, Lusardi and Mitchell (2007a) test the possible causal effect of wealth on financial planning using changes in regional housing prices as an instrument for wealth, but they limit their study to older respondents in the U.S. Health and Retirement Study and do not consider the possible impact of financial literacy on wealth as we do in this study. Bernheim, Garrett, and Maki (2001), Cole and Shastry (2009), and Lusardi and Mitchell (2009) investigate how changes in U.S. schooling laws and state mandates requiring schools to offer financial literacy relate to financial market participation, but these studies do not focus on wealth accumulation as we do here. Ameriks, Caplin, and Leahy (2003) explore instruments for planning by U.S. respondents but they are silent on the role of financial literacy.

${ }^{3}$ The Social Protection Survey is described at www.microdatos.cl/interior_areasMT.php?id_s=2\&id_ss=2\&id_proy=1

${ }^{4}$ Ameriks et al. (2003) examine highly-educated TIAA-CREF survey participants; Lusardi and Mitchell (2007a) use Health and Retirement Study respondents over age 50. In contrast, the dataset we use below is a nationally representative sample of men age 24-65 and women age 24-60.
} 
on wealth, we show that both financial literacy and schooling attainment are positively associated with wealth outcomes. Moreover, our IV estimates indicate even stronger effects of financial literacy on wealth than suggested by OLS models, while the opposite is true for schooling in linear specifications; interactive specifications imply that both schooling and financial literacy have significant positive effects.

Our results are relevant for financial educational policy in that we find that improved financial literacy can make a significant difference for financial behavior, even after controlling for schooling. This rigorous analysis of the impact of financial literacy on wealth accumulation should be useful in informing governments and their policy advisers around the world, as they consider new initiatives for financial education. ${ }^{5}$

\section{Empirical Framework}

Several prior studies have shown that financial literacy and schooling are significantly correlated with positive financial behavior, but few have controlled for (usually) unobserved factors such as risk aversion, self-esteem, innate ability, intelligence, and motivation that may shape the relationship between financial literacy and financial behaviors. ${ }^{6}$ For this reason, it is difficult to conclude, based on the scientific evidence, that improvements in financial literacy actually enhance financial planning and saving, or whether, instead, wealth and financial literacy are both the result of some other unobserved factors. For this reason, analyses that do not control for such unobserved factors may be vulnerable to biases in the estimated effects of schooling and financial literacy on financial wellbeing. Moreover, empirical indicators of schooling and financial literacy are noisy measures, and as is well-known, random measurement error in rightside variables tends to bias their coefficient estimates towards zero. Estimates of noise-to-signal ratios for schooling attainment are often about 10 percent (Ashenfelter and Krueger 1994; Behrman, Rosenzweig, and Taubman 1994), producing a bias towards zero of almost that magnitude. Measures of financial literacy are likely subject to greater measurement errors, and

\footnotetext{
${ }^{5}$ For instance the World Bank and the Russian Federation have recently announced a multi-million dollar, multiyear collaborative to improve financial literacy in low- and middle-income countries (see http://web.worldbank.org/WBSITE/EXTERNAL/TOPICS/EXTEDUCATION/0,,contentMDK:21936796 menuPK:2643854 pa gePK:64020865 piPK:149114 theSitePK:282386,00.html)

${ }^{6}$ Both Lusardi (2003) and Ameriks et al. (2003) use IV strategies, but they focus on financial planning rather than financial literacy.
} 
thus, greater biases. Instrumental variable estimates are one way to eliminate the attenuation bias towards zero due to measurement error.

Our goal is to assess whether wealth accruals could be enhanced with greater financial literacy and schooling. Suppose the true relationship between financial literacy, schooling, and wealth could be described for the ith person as:

$$
W_{i}=\beta_{0}+\beta_{1} F L_{i}+\beta_{2} S_{i}+\beta_{3} F L_{i} * S_{i}+\beta_{4} C_{i}+\beta_{5} E_{i}+\varepsilon_{i},
$$

where wealth $W_{i}$ depends linearly on financial literacy $F L_{i}$, schooling $S_{i}$, their interaction $F L_{i} * S_{i}$, other observed individual characteristics $C_{i}$, unobserved individual characteristics $E_{i}$, and unobserved random shocks $\varepsilon_{i}$. We include in relation (1) both linear terms in $F L_{i}$ and $S_{i}$ and their interaction. We include the interaction because it is possible that the effects of financial literacy $F L$ depend on the level of schooling $S_{i}$ and vice versa. This coefficient of this interaction term may be positive if financial literacy $F L_{i}$ and schooling $S_{i}$ are complements and reinforce each other or negative if they are substitutes in determination of wealth accumulation. Below we consider three variants of relation (1):

(1a) only linear terms, ${ }^{7}$

(1b) both the linear and interaction terms, and

(1c) only the interaction term.

Equation (1) posits that there are no other endogenous variables beyond financial literacy and schooling that directly determine wealth. For example, the time one devotes to schoolwork and how that time is divided between arithmetic and other topics might affect wealth, but our assumption is that such effects are indirect via financial literacy and schooling. Likewise, there could be other behavioral channels through which $F L_{i}$ and $S_{i}$ affect $W_{i}$. For instance, part of the effects on wealth may work through choosing to contribute more to pensions, or by increasing understanding of business news and market predictions. Estimating equation (1) does not illuminate such possibilities, though formulations similar to equation (1) but using some saving pathway as the dependent variable could illuminate the roles of $F L_{i}$ and $S_{i}$ in determining the relevant mechanism. In what follows, we offer analysis of two such pathways, the density of pension contributions and whether the individual attempted to calculate money needed for retirement.

\footnotetext{
${ }^{7}$ We also consider two sub-variants of the linear case with only financial literacy or only schooling.
} 
We further posit that financial literacy and schooling are determined by observed personal characteristics $C_{i}^{*}$ (that may overlap with $C_{i}$ ), some factors in $\mathrm{C}^{*}$ and $X_{i}$ that affect learning and schooling but do not directly affect $W_{i}$, unobserved individual characteristics $E_{i}$, and error terms $u_{i}$ and $v_{i}:{ }^{8}$

$$
\begin{aligned}
& F L_{i}=\eta_{0}+\eta_{1} C_{i}^{*}+\eta_{2} X_{i}+\eta_{3} E_{i}+u_{i} \\
& S_{i}=\alpha_{0}+\alpha_{1} C_{i}^{*}+\alpha_{2} X_{i}+\alpha_{3} E_{i}+v_{i}
\end{aligned}
$$

In general, for consistent estimates of the coefficients of interest, ordinary least squares (OLS) regression requires that the covariance between the disturbance terms in equations (1) and (2) and (1) and (3) be zero: that is, there can be no unobserved factors that are correlated with financial literacy or schooling but also affect the outcome of interest $W_{i}$. Nevertheless, the unobserved individual factors vector $E_{i}$ appears in the compound disturbance terms for all relations, implying that OLS estimates are likely to suffer from omitted variable bias. The direction of the bias depends on whether the true values of $\beta_{5}$ and $\eta_{3}$ (and similarly, of $\beta_{5}$ and $\alpha_{3}$ ) have the same or the opposite signs. For example, if the unobserved factor is ability that positively affects financial literacy and also directly positively affects wealth, both $\beta_{5}$ and $\eta_{3}$ are positive and OLS estimates of $\beta_{1}$ are biased upward, overestimating the magnitude and significance of financial literacy as a determinant of wealth. Conversely, if some unobserved factor such as innate caution produced greater investment in financial literacy, but ceteris paribus reduced wealth due to too great caution in investment behavior, OLS estimates of $\beta_{1}$ are biased downward, underestimating the magnitude and significance of financial literacy as a determinant of wealth accumulation. In addition to the possibility of such omitted variable biases, financial literacy and schooling measures are potentially subject to measurement error as noted above, which would tend to bias OLS estimates towards zero.

\footnotetext{
${ }^{8}$ We also could include another equation parallel to (2) and (3) for the interaction, but since the points made here for the case in which $F L_{i}$ and $S_{i}$ enter in equation (1a) only linearly carry over to the case with the interaction, we limit this discussion to the simpler case in which they only enter linearly. We have written equations (2) and (3) as if $F L_{i}$ and $S_{i}$ have the same determinants except for $u_{i}$ and $v_{i}$, which are likely to be correlated (perhaps perfectly correlated). This is the usual setup in household models if decisions regarding $F L_{i}$ and $S_{i}$ are made at the same time - in principle, all concurrent decisions are made in light of all the variables that determine household behaviors though, of course, the coefficients could differ and some may not be significantly different from zero. If decisions are made at different times, the right-side determinants in equations (2) and (3) may differ; for example, some expectations that determine the earlier decision could be replaced by realized outcomes that occurred prior to the later decision. Our microeconomic dataset, like most, does not permit empirical representations of such possibilities.
} 
A similar point holds with regard to estimates that include only $F L_{i}$ or only $S_{i}$ - one at at a time - if the true relation is actually equation (1a) with both entering linearly. ${ }^{9}$ Equations (2) and (3) show that it is highly likely that $F L_{i}$ and $S_{i}$ are correlated because their determinants are basically the same. ${ }^{10}$ Accordingly, if the true relation is equation (1a) with both $F L_{i}$ and $S_{i}$ entering linearly but analysts include either $F L_{i}$ or $S_{i}$, the coefficient estimate for the included variable is biased because it is correlated with the excluded factor.

To handle this problem, we use an IV approach with robust standard errors to estimate the three variants of equation (1) in light of (2) and (3), seeking to isolate the causal effects of financial literacy and schooling, and to control for random measurement errors. Good instruments are ones that are sufficiently correlated with financial literacy $F L_{i}$ and with schooling $S_{i}$, but that are independent of unobserved effects in equation (1) determining wealth. The $X_{i}$ vector and elements of the $C_{i}^{*}$ vector excluded from $C_{i}$ in equations (2) and (3) refer to such instruments. For the IV estimation, we begin by estimating the "first stage" determinants of financial literacy and schooling in (2) and (3); next we use these estimates to predict financial literacy and schooling and employ them in the "second stage" estimate of equation (1). Note that with the above assumptions, predicted financial literacy and predicted schooling are independent of the compound error term in (1). Therefore, if equation (1) is the true relation, the IV or twostage least squares procedure leads to consistent estimates of $\beta_{1}$ and $\beta_{2}$.

In what follows, we utilize a set of plausible instruments and diagnostic tests to determine whether our instruments are (a) sufficiently strong (using F tests for excluded instruments, Angrist-Pische multivariate $\mathrm{F}$ tests for excluded instruments, and the Kleibergen-Paap weak identification tests), and (b) independent of the second-stage compound disturbance term $\left(\beta_{4} E_{i}+\right.$ $\varepsilon_{i}$ ) using the Hansen J statistic overidentification test. ${ }^{11}$ Our candidate instruments, on which we elaborate below, include (1) age-related factors such as governmental policies and

\footnotetext{
${ }^{9}$ Some other endogenous variable $Y_{i}$ might also be included in equation (1) but our maintained hypothesis for our estimates, as in other instrumental variable estimates, if that this is not the case.

${ }^{10}$ It is possible but highly unlikely in such household models that the coefficients of the variables in equations (2) and (3) differ so that financial literacy and schooling are orthogonal.

${ }^{11}$ There recently has been what Stock (2010) calls a "transformation" in econometric tools for making inferences, including development of some of the diagnostic tools that we use here(see Stock (2010) and the references therein). As is well-known, the J statistic only tests the overidentifying restrictions, not the exogeneity of all the first-stage instruments (e.g., Stock and Watson 2007, Wooldridge 2002). As also is well known (e.g. Wooldridge 2002), the failure to reject the null in overidentification tests may be because the test has low power for detecting the endogeneity of some of the instruments. As discussed below, however, in our case, the overidentification test does have power to reject a number of candidate instruments.
} 
macroeconomic conditions, (2) family background, and (3) personality traits. We find that many of these candidates are good by conventional criteria. Nevertheless, some are insufficiently strong predictors of the endogenous $F L_{i}$ and $S_{i}$ right-side variables, and some are not independent of the second-stage disturbance term. Therefore, arguably, this latter group should be included as controls in the second-stage relation (i.e., in the vector $C_{i}$ in relation 1).

\section{Data and Descriptive Statistics}

Our primary data source is the Social Protection Survey (Encuesta de Protecion Social, EPS) administered by us in collaboration with the Microdata Center of the University of Chile (Arenas et al., 2008; Bravo et al. 2004, 2006, 2010). This survey is comparable to the U.S. Health and Retirement Study (HRS) that provides a nationally-representative stratified random survey on respondents over the age of 50, covering, inter alia, their wealth, schooling, financial literacy, work history, childhood background, and selected personality traits. In contrast to the HRS, however, the EPS covers all adults, not just respondents over age 50. In what follows, we limit our attention to 13,054 prime-age respondents surveyed in 2006, namely men age 24-65 and women age 24-60 (since in Chile the legal retirement age is 60 for women but 65 years for men). As noted below, we also have linked these data to some information on policies, markets and macroeconomic conditions at critical junctures in respondents’ lives.

Wealth and Pension Contribution Outcomes: Our outcomes of interest are components of net wealth, drawing on four EPS measures summarized in Table 1 (wealth in US\$2006):

- Pension wealth averages $\$ 38,600$ or 54 percent of total net wealth, though with considerable variance across respondents and about a quarter (25 percent) of respondents have zero pension wealth. In 1981, the Chilean government terminated the old insolvent pay-as-you-go retirement system and replaced it with a national, mandatory defined-contribution scheme known as the AFP system (Mitchell, Todd, and Bravo, 2008). This reform required all new formal sector employees to contribute at least 10 percent of their salaries to one of several licensed defined contribution pension funds. ${ }^{12}$ We believe that pension wealth is likely to be relatively accurately

\footnotetext{
12 Those who started working prior to 1980 could elect to join the new scheme or remain covered by the previous system.
} 
reported in Chile because respondents receive annual statements from the government summarizing their defined contribution pension system accruals.

- Net housing wealth averages $\$ 22,100$ or 31 percent of total wealth, again with considerable variance across respondents (though with a standard deviation only about half as large as for pension wealth despite a greater range); about a quarter (26 percent) of respondents report none and 1 percent report negative net housing wealth. We calculate net housing wealth based on self-reported data on market values (either for sale or for rent) minus estimated mortgage debt. Our measure of housing wealth is probably noisier than our measure of pension wealth and some of the other wealth components.

- Other net wealth averages $\$ 10,600$ or 15 percent of total net wealth, with greater variance across respondents than either pension or housing wealth but again about a quarter (25 percent) of respondents report zero and more (31 percent) report negative values. We calculated other net wealth by summing self-reported business wealth, agricultural assets, other real estate assets, and financial investments and subtracting all forms of household debt. This other net wealth measure probably also is a noisier than the measure of pension wealth.

- Total net wealth averages $\$ 71,500$, with greater variance and greater range than the other wealth measures just described. Total net wealth is the sum of the three components above.

\section{Table 1 here}

In addition to these wealth measures, we also explore two possible channels via which financial literacy and schooling might affect particularly pension wealth. The first is the "density of pension contributions." This concept refers to the fraction of months each individual contributed to the pension system, from age 18 to the survey date, and therefore is indicative of how attached the worker is to the pension saving system. We derive this measure by tracking respondent self-reports of the number of months they worked in covered jobs over time and contributed to a pension fund, compared to the number of months when they could have contributed. On average respondents report that they contributed to their pension almost half the 
time they were eligible to do so, though there is again wide dispersion over the sample. ${ }^{13}$ About 10 percent of individuals contributed all of the available time, while 17 percent report they never contributed. The second channel that we explore is a retirement planning indicator of whether the individual has attempted to calculate the money he or she needs for retirement. The survey question for this retirement planning variable is as follows:

- Have you attempted to calculate the money needed in order to retire? [yes/no]

We create a dummy indicator in which 1 indicates a yes response, and 0 represents a negative response.

Explanatory Variables: Schooling and Financial Literacy: Our key explanatory variables are schooling attainment and financial literacy. Schooling attainment is measured in a fairly conventional manner (e.g., Bravo, Mukhopadhyay, and Todd 2010), with primary school referring to grades 1-8, secondary school to grades 9-13, and post-secondary school to grades beyond that, to a maximum of 20. The average schooling attainment in our sample (see Table 2) is 10.4 grades, with a standard deviation of 3.9 grades. Only about one percent of the respondents have no schooling, and about the same fraction has the maximum of 20 years.

Table 2 here.

Financial literacy is measured using a rich set of 12 questions. The first three 'core' questions cover basic economics and finance including an understanding of risk and simple interest; the second more 'sophisticated' set of three pertains to more elaborate financial concepts; and a third set of six covers knowledge of retirement system rules including the legal retirement age and how to calculate AFP pension benefits.

The "core” first three financial literacy queries were developed and implemented in the HRS (Lusardi and Mitchell, 2007c); they have also been adopted by several other international surveys. They are as follows:

- If the chance of catching an illness is 10 percent, how many people out of 1000 would get the illness?

- If 5 people share winning lottery tickets and the total prize is 2 Million pesos, how much would each receive?

- Assume that you have \$100 in a savings account and the interest rate you earn on this money is 2 percent a year. If you keep this money in the account for 5 years, how much would you have after 5 years? [more than $\$ 120$, exactly \$120, less than \$120]

\footnotetext{
${ }^{13}$ Our density estimates conform to those reported in Arenas et al. (2008).
} 
The second more sophisticated set of three questions has also been fielded in a special HRS module (Lusardi and Mitchell, 2009) intending to measure more complex concepts such as compound interest, inflation, and risk diversification. The specific questions are:

- Assume that you have \$200 in a savings account, and the interest rate that you earn on these savings is 10 percent a year. How much would you have in the account after 2 years? [exact number]

- Assume that you have $\$ 100$ in a savings account and the interest rate that you earn on these savings is 1 percent a year. Inflation is 2 percent a year. After one year, if you withdraw the money from the savings account you could buy more/less/the same?

- T/F: Buying shares in one company is less risky than buying shares from many different companies with the same money.

The third set of questions is specific to the EPS, and it touches on some of the key aspects of the Chilean retirement system focusing on the mandatory contribution rate, the legal retirement age for women and men, how pension benefits are computed in the defined contribution system, whether people are aware of the government's welfare benefit for the elderly, and whether people know they can contribute to the Voluntary Pension system even when they are not in covered-sector jobs. The specific wording of these questions is:

- Do you know what percentage of income is (has been or would be) deducted monthly for pension system contributions? [yes/no]

- Do you know the legal retirement age for women? [60]

- Do you know the legal retirement age for men? [65]

- Do you know how to calculate pensions in the AFP? [yes, by balance of individual account and other elements such as age of retirement]

- Do you know there is a minimum state guaranteed old age pension for people aged 65 and over? [yes/no]

- Have you heard of the Voluntary Pension Savings system introduced in 2002? [yes/no]

Table 3 lists all 12 financial literacy questions along with a summary of how the individuals in our sample answered them. As is clear from Column 1, only half of the respondents knew the correct answer to the core questions (1-3), and fewer knew the sophisticated financial literacy questions (4-6). While people did score relatively well on the risk diversification question, they could have been guessing as only a true/false response was required. ${ }^{14}$ Patterns are more variable for questions regarding knowledge of pension system benefit rules and provisions: most knew the legal retirement ages, but only about one-third knew the mandatory contribution rates and only 10 percent could say how benefits are computed.

\footnotetext{
${ }^{14}$ This pattern is similar to that reported for India and higher than for Indonesia (Cole, Sampson, and Zia 2009).
} 
About half the sample knew about both the guaranteed minimum benefit and the Voluntary Savings plan.

Table 3 here

Previous authors have measured financial literacy by selecting one or two key questions and reporting whether respondents answered each one correctly (Lusardi and Mitchell, 2007a). With such a rich set of financial literacy measures available in the EPS, however, it is inefficient to limit ourselves to a question or two; instead, we seek to use all the information contained in the dozen questions. A conventional way to aggregate responses would be to assign one point to each question answered correctly and calculate an overall percentage correct score. Yet this approach has the disadvantage of weighting each question equally and hence does not allow distinctions among questions either in difficulty or information.

A more sophisticated approach to measuring financial literacy employs a weighted scoring mechanism called PRIDIT, first designed to deal with difficult-to-observe outcomes where indicator variables that proxy for the dependent variable are binary or categorical. For example, Brockett et al. (2002) use the approach to assess insurance fraud, where investigators use several indicator variables (such as whether an individual had time gaps between medical treatments or experienced many hospital visits) to assess whether a given claim might be fraudulent. PRIDIT has also been used in the health economics field to evaluate hospital care, where indicators of quality are used to generate a 'best' or most informative quality index (Lieberthal, 2008).

In what follows, we use the PRIDIT approach to develop financial literacy scores and highlight which questions are the most informative indicators of financial literacy. ${ }^{15}$ This approach involves a two-step weighting scheme, where the first step links each individual's responses on particular questions to others' responses to the same question. One goal is to determine which questions are more difficult - ones that few people answer correctly - and then it gives more credit to particularly difficult questions that few people can answer correctly. A simple aggregation would simply assign zero credit for an incorrect answer and a full point for each correct answer; by contrast, PRIDIT applies a negative penalty for an incorrect answer and a greater penalty for a question that more of the population answers correctly. As an example, a small fraction of the sample answered question 4 correctly (Table 3, Column 1), so question 4 is

\footnotetext{
${ }^{15}$ A related approach was implemented in Mitchell et al. (2008) in an analysis of pension switching patterns.
} 
considered a difficult question. Consequently, answering question 4 correctly is assigned a greater reward, while answering it incorrectly results in only a relatively small penalty. Unlike simple integer scoring, this method captures the degree and direction to which an individual's response stands out relative to the population.

The second PRIDIT step applies a principal components analysis to take into account correlations across questions. ${ }^{16}$ The resulting PRIDIT scores indicate how financially literate an individual is in relation to the average population and to specific questions asked. Questions tend to be informative, ceteris paribus, the less they are correlated with other questions. The bivariate correlations are suggestive though not conclusive in this regard, because correlations of the answers to a question with a linear combination of the answers to other questions may differ from the bivariate correlations. The bivariate correlations among the correct answers to the questions vary considerably, from 0.04 (for the correlations between question 4 and questions 8, 9, and 11) to 0.63 (for the correlation between questions 8 and 9). Also the mean correlations of each question with the other 11 questions vary considerably, with those for questions 4 and 10 only about half of those for questions 1, 2 and 12 (third column from right in Table 3). By this criterion, in isolation, questions 4 and 10 seem to be relatively important. But this is not the only criterion. Questions also tend to be more important on average, ceteris paribus, if the proportions correct are closer to one half, rather than almost zero or almost one. The intuition for this is clear by considering the extremes: questions for which the proportion correct is zero or one provide no information because the answers are the same for everyone, whereas questions for which the proportion correct is close to zero or close to one provide substantial information to distinguish among those in the tails of the distribution. However, if the distribution of the underlying latent variable for true financial literacy is normal, relatively few individuals will be in the tails of the distribution, versus in the middle. By this criterion, questions 4 and 10 are relatively unimportant, particularly in comparison to the three 'core' HRS questions (1-3) and questions 6, 11 and 12 (penultimate column in Table 3).

The last column of Table 3 reports PRIDIT weights for each question that are indicative of how "informative" a given question is regarding the underlying latent financial literacy

\footnotetext{
${ }^{16}$ Specifically, we calculate the first principal component vector for each of the 12 questions and the eigenvalue of the first principal component. The eigenvector with the largest eigenvalue captures more of the variance in the data than any other eigenvector. Using these values, we then calculate a weight for each question that gives more weight to questions that are more informative on financial literacy.
} 
variable, relative to other questions based on both criteria. The 'core' HRS financial literacy questions receive the greatest weight compared to the other financial literacy questions included in the EPS. Next most informative are the queries on pension system knowledge (e.g. question 7 "Do you know what percentage of income is deducted for monthly pension system contributions?" and question 12 "Have you heard of the Voluntary Pension Savings system introduced in 2002?”). Despite being most informative by the criterion of being least correlated with other questions, question 4 "Assume that you have \$200 in a savings account, and the interest rate that you earn on these savings is 10 percent a year. How much would you have in the account after 2 years?" and question 10 "Do you know how to calculate pensions in the AFP?") have the smallest PRIDIT weights because of the second criteria discussed in the previous paragraph (i.e., proportions correct close to zero).

The PRIDIT score thus computed is highly correlated with a simple percentage correct tally, and results using either type of aggregation are very similar. Nevertheless, we favor the PRIDIT approach as it incorporates additional information about the relative difficulty of each question and value-added of each question, and we use it in estimates presented below.

Control Variables. Demographic controls included in our specification for equation (1) include Age in a quadratic form to account for the typical hump-shaped life-cycle pattern of wealth accumulation. The mean age of our respondents is 43 years, with a standard deviation of 11 years. We also control on the variable Male, a dichotomous variable to allow for shifts on average between wealth accumulations for men versus women. Just over half (52 percent) of our respondents are male.

We do not include in the set of controls any variables likely to be determined in part by schooling and financial literacy, and hence possibly affect wealth, such as marital status and current residence. ${ }^{17}$ We do include as controls some of the candidate instruments that do not satisfy the second condition for a good instrument, independence of the disturbance term in equation (1), which are apparently correlated with factors that have direct effects on wealth

\footnotetext{
${ }^{17}$ We adopt this approach because we are interested in the gross effect of schooling and financial literacy, not net of effects through such behaviors as marital status and current residence. Moreover, if we were to include such variables it would be necessary to treat them as endogenous, but it is difficult to increase the number of endogenous variables beyond the two on which we focus. For this reason, our approach thus assumes that these are among the channels through which schooling and financial literacy work to affect wealth. (Below we explore the robustness of our estimates to the inclusion of such factors in the second-stage estimates, but without treating them as behaviorally-determined.)
} 
accumulation in addition to any effects that work through schooling and financial literacy. We indicate which variables these are in our discussion of the results below.

Candidate First-Stage Instruments: As is generally the case, we cannot identify good instruments a priori, only possible candidate instruments that might predict schooling and financial literacy well, while not being correlated with the second-stage disturbance. Even experiments that directly affect schooling and financial literacy might not be good instruments if they have weak effects on schooling and financial literacy (and therefore do not satisfy the first condition), or if they affect wealth directly through some other channel than schooling and financial literacy (and therefore do not satisfy the second condition). In what follows, we consider as three broad sets of candidate instruments: Age-dependent variables, Family Background factors, and Respondent Personality traits. We describe each in turn.

For the Age-dependent variables, we include factors indicative of where the respondents attended primary school as children, how old they were when an innovative national voucher program was implemented by the government in 1981, what macroeconomic conditions were when they were of an age to have been making marginal schooling and labor market entry decisions, and what pension marketing practices prevailed when they were of an age to have completed initial job searches and to have settled in more permanent positions. These four variables are as follows:

- Primary School in Urban Area: In Chile, as in many countries, urban primary schools on average tend to be better and have a wider range of options, which may lead to more learning relevant for financial literacy and greater schooling attainment. Chile is a fairly urban country and 81 percent of the respondents did attend primary school in urban areas.

- School Voucher Exposure (years of school age under voucher system): In 1981, the Chilean government adopted a national school voucher system for primary and secondary school. Anyone turning age 18 prior to 1981 therefore had no exposure, whereas younger individuals had varying numbers of years of exposure to the new school voucher program. We posit that this exogenous policy change may have had significant effects on individual schooling attainment and financial literacy. At the same time, the introduction of school vouchers could also have had direct effects on wealth accumulation through increasing schooling quality, beyond direct effects on financial literacy and schooling attainment. For instance, Bravo, Mukhopadhyay, and Todd (2010) report that this 
schooling reform improved schooling quality and resulted in subsequent higher labor market earnings for adults exposed to the voucher system when they were children. Our respondents averaged 2.2 years of exposure to the voucher system when they were of primary school age and 1.8 years of exposure to the voucher system when they were of secondary school age, but with a fair amount of variance among respondents depending on when they were born. In fact, a substantial majority of our respondents (73 percent) had no exposure to the school voucher system at all due to having been older than age 18 at the time of the reform.

- Macroeconomic conditions around the time of the school-leaving/labor-market-entry decision: It is also likely that the state of the macroeconomy around the age respondents made school-leaving and labor market entry decisions influenced both their schooling attainment and financial literacy. For this reason we control for the unemployment rate in the Santiago metropolitan area at the time the individual was age 16, since these rates (but not national rates) are available for a sufficiently long time period and a large fraction of the population lives in the capital city.

- Pension marketing activities around end of early adult job search: We also posit that AFP marketing agents and expenditures early in a respondent's work life could increase financial literacy, by enhancing awareness of wealth accumulation in general and of pensions in particular. Accordingly, we measure the number of marketing agents and AFP marking expenditures around the time the individual completed initial labor market search and settled down in more permanent employment, around age 24. But such AFP marketing activities might also have direct effects on wealth accumulation in addition to indirect effects through financial literacy (or possibly schooling, though most respondents completed their schooling prior to age 24), a pathway we test below. In fact, there was substantial variation in the number of AFP marketing agents and marketing expenditures across respondent birth cohorts; at the same time, almost 40 percent of respondents were older than 24 before the AFP system was implemented, so for them marketing activities around this age were zero.

We posit that these four conditions are unlikely to have been affected by conscious decisions by either the respondents when they were young, or their families, to increase respondents' subsequent wealth levels. That is, we assume that respondents' parents did not move to urban 
areas when the children were in primary school for reasons correlated with the respondents' later wealth accumulations, and that neither the respondents nor their parents could affect national schooling voucher policies, macroeconomic conditions, or AFP marketing. Nevertheless, some of these variables might not satisfy the second condition for good instruments, as we note above and test in the empirical work.

For the Family Background Variables, it is well-known that there are strong empirical links between family background and schooling attainment, and family background is included among instruments in some previous studies where schooling attainment is a right-side explanatory variable. ${ }^{18}$ We argue that a similar association exists with financial literacy (though there is no literature to date on the topic), and accordingly family background should meet the first condition for a good financial literacy instrument as well. Nevertheless, it seems a priori plausible that family background could also proxy for factors such as intergenerationally correlated ability endowments via channels other than schooling and financial literacy that directly affect wealth. ${ }^{19}$ Accordingly, we include indicators of family background in our set of candidate instruments, but we test whether they satisfy the second condition for being good instruments. The specific family background indicators we include are:

- Paternal and Material Schooling Attainment: These averaged 7.2 and 6.6 grades, respectively, indicating considerable intergenerational increases in schooling attainment given the respondents' average of 10.4 grades of schooling completed.

- Poor Economic Background when Child: Some eight percent of respondents characterized their childhood family economic background as poor.

- Respondent Worked when Under 15 Years of Age: Child labor generally is associated with poorer family backgrounds; in our sample; 7 percent of respondents reported that they had started to work when younger than 15 years of age.

Respondent Personality Traits are enduring individual characteristics that generally reflect genetic endowments and earlier life experience rather than states that change over fairly short time periods for adults. McCrae and Costa (1990), for example, report that both many longitudinal studies following the same individuals over time and cross-sectional comparisons

\footnotetext{
${ }^{18}$ See Hanushek and Welch (2006), as well as studies mentioned in the next note and the citations therein.

${ }^{19}$ For example, studies of the impact of maternal schooling on child schooling find that significantly positive associations become much smaller or even reversed in sign if estimation techniques using twins data, adopted children, or policy changes are used to control for unobserved intergenerationally-correlated endowments such as ability (e.g., Behrman and Rosenzweig 2002, 2005; Black, Devereux, and Salvanes 2005; Plug, 2004).
} 
across different age groups show a high degree of stability in personality traits during adulthood. ${ }^{20}$ Heritability variance decompositions using twins data typically attribute half (and sometimes much more) of the overall variance of personality traits to genetic variation, and the remaining variance is mostly due to early life experience. ${ }^{21}$ For this reason, we posit that some personality traits observed in our data are relatively stable and may have significant effects on schooling and financial literacy. Of course they may also have direct effects on wealth accumulation in addition to indirect effects through schooling and financial literacy, and thus they could violate the second condition for good instruments, something that we also test below. The specific variables we use from the EPS are as follows:

- Risk Aversion, referring to a respondent's reluctance to accept a risky but possible more rewarding alternative versus a choice with a more certain but lower expected payoff. This is measured using a dichotomous variable for a positive answer for Alternative A to the following question: ${ }^{22}$

Suppose that you, as the only source of household income, have to choose between the following two jobs. What alternative would you choose in [this] situation?

Alternative A. A fixed income job that is stable for life. Alternative B. A job where you have the same possibility of earning double or only three quarters of your income for the rest of your life.

By this measure almost two-thirds (65 percent) of our sample is risk averse. ${ }^{23}$

- Self Esteem is used by psychologists to refer to an individual's overall evaluation of his or her own worth (Mruk 2006). For empirical research, this is usually assessed with a

\footnotetext{
${ }^{20}$ For some other examples see Kahnemann (1999:14) who argues that, with respect to wellbeing or happiness, "each individual may be on a personal treadmill that tends to restore well-being to a predetermined setpoint after each change of circumstances." Csikszentmihalyi and Jeremy (2003: 185-186) conclude that "chance events like personal tragedies, illness, or sudden strokes of good fortune may drastically affect the level of happiness, but apparently these effects do not last long." And Costa et al. (1987: 54) report that "objective circumstances appear to be limited in the magnitude, scope, and particularly duration of their effects on psychological well-being, which, in the long run, is likely to reflect instead stable characteristics of the individual." Easterlin (2005) reviews the psychological literature with respect to this "set-point theory" of happiness.

${ }^{21}$ Lykken and Tellegen (1996) report that variation in the well-being component of the Multidimensional Personality Questionnaire for twins in the Minnesota Twin Registry is primarily associated with genetic variation; that is, genetic effects account for up to 80 percent of the variance in happiness indicators obtained by averaging repeated measures of well-being. Moreover, socioeconomic status, schooling, family income, marital status, and religious commitment do not account for more than three percent of the variance in these averaged measures of well-being. In another example, Bouchard and McGue (2003) summarize the estimated heritabilities for the "Big Five" personality traits to be about one-half.

${ }^{22}$ This is third question in a series of three alternative pairs, where the previous two indicate riskier options for Alternative B.

${ }^{23}$ For other recent studies linking risk aversion and economic behavior, see Dohmen et al. (2010 a, b), Eckell et al. (2005); and Guiso et al. (2005, 2008). Borghans, Duckworth, Heckman and ter Weel (2008) provide another recent discussion about personality traits and economics.
} 
self-report inventory such as the Rosenberg Self-Esteem Scale that usually uses a 10question battery scored on a four-point response system that requires participants to indicate their level of agreement with a series of statements about themselves. The 2006 EPS applied a version of the Rosenberg test as follows:

Finally, we ask about the level of agreement or disagreement with the following statements: [Scale: 1. Strongly Disagree, 2. Disagree, 3. Agree, 4. Strongly Agree]

1. I feel that I am a valuable person, at least with respect to others

2. I feel that I have a number of good qualities

3. I definitely tend to think that I am a failure

4. I can do things as well as other people

5. I do not feel that I have much to be proud of

6. I have a positive attitude about myself

7. All in all, I am happy with myself

8. I would like to have more self-respect

9. I sometimes feel useless

10. I sometimes feel that I am good for nothing.

In our analysis, we focus on a measure of positive self-esteem defined as the sum of the answers to questions 1, 2, 4, 6 and 7, as well as a measure of negative self-esteem defined as the sum of the answers to questions 3, 5, 8, 9 and $10 .^{24}$ Both sums range from 1 to 20, with a mean for positive self-esteem of 16.1 and for negative self-esteem of 10.5. Each of the five respective components in each sum is weighted equally, so we also investigate whether any of the components has significantly different effects than the sums.

Finally we also include a vector of other respondent characteristics for robustness tests in some alternative specifications. We do not include these in our basic estimates because many could argue they are endogenous, including residence in the Santiago metropolitan area at the time of the survey (38 percent), self-reported bad (6 percent) or good health (69 percent), being never married (23 percent) or married at the time of the survey (66 percent), being a household head (56 percent) or spouse of household head (24 percent) at the survey date.

\section{Ordinary Least Squares Estimates}

Since most prior studies have used ordinary least squares (OLS) models that did not treat schooling and financial literacy as behaviorally determined or imprecisely measured due to

\footnotetext{
${ }^{24}$ We also considered a combined index defined as positive self-esteem - negative self-esteem, but the two separate indices have greater predictive power so we include them separately in our estimates.
} 
random measurement errors, we also begin with OLS estimates to describe the associations among schooling, financial literacy, and the wealth, pension density and retirement planning outcomes. Results appear in Table 4 (control variables are identical to those used later in IV models so estimates can be compared across results).

\section{Table 4 here}

Panel I of Table 4 reports estimated coefficients for a specification that includes only the PRIDIT index of financial literacy and excludes schooling (equation 1a-subvariant 1). Results indicate that the PRIDIT index is positive and strongly statistically significant in all four wealth equations, the density of pension contributions, and the probability of calculating the money needed for retirement. Moreover, the estimates are quantitatively important, implying that a 0.2 standard deviation increase in the PRIDIT index (taken from Table 2) is associated with an average \$4,000 increase in net wealth, or almost 6 percent increase in mean net wealth. The largest response is for pension wealth $(\$ 2,200)$, with other wealth $(\$ 1,000)$ and housing wealth (\$800) less than half as large. A 0.2 standard deviation increase in PRIDIT is also associated with an average increase of 1.4 percent in the density of pension contributions and 0.8 percent increase in the probability of calculating the money needed for retirement.

Panel II of Table 4 provides coefficient estimates for an OLS specification that includes schooling as an explanatory variable but excludes the PRIDIT financial literacy measure (equation 1a-subvariant 2). Schooling coefficient estimates are positive and highly significant for all four wealth measures, the density of pension contributions, and retirement planning. Moreover they are substantial and even somewhat larger than the PRIDIT effects in that they imply that that a 0.2 standard deviation increase in schooling (taken from Table 2) is associated with an average \$5,900 increase in net wealth, or 8.3 percent of mean net wealth. The largest component of this overall wealth increment again is pension wealth $(\$ 3,000)$, with other wealth $(\$ 1,600)$ and housing wealth $(\$ 1,300)$ taken together almost as large. A 0.2 standard deviation increase in schooling is associated with an average increase of 1.4 percent in the density of pension contributions and 0.6 percent increase in the probability of calculating money needed for retirement.

Yet the PRIDIT financial literacy index and schooling are significantly positively correlated $(\mathrm{r}=0.51)$, so their coefficients estimates are anticipated to change when both are included in the same regression. Indeed this is the case, as is shown in Panel III of Table 4 
(equation 1a), where the PRIDIT coefficient estimates drop by a quarter for the density of pension contributions to two-thirds for housing wealth, with total wealth in between, dropping by half. The schooling coefficient estimates also decline, though by less, around 10 percent for housing wealth and 16 percent for total wealth. Consequently, one can conclude that including only one of these two explanatory variables in OLS regressions produces larger estimates for each, than if both are included. Nevertheless, when both are included, the associations remain significant and fairly large in magnitude for both.

As noted in the discussion of equation (1), having only linear terms for schooling and financial literacy is but one possible specification choice. Adding interactions between schooling and the PRIDIT financial literacy index in addition to the linear terms alters the results somewhat (Panel IV of Table 4, equation 1b). The linear schooling coefficient estimates remain about the same magnitudes as without the interaction term, and they are estimated with greater precision. Yet the linear PRIDIT coefficient estimates become negative and significant for three of the four wealth outcomes (of course, the total association of PRIDIT with the wealth outcomes for any schooling attainment must include the interaction with schooling attainment). For the density of pension contributions, in contrast, the coefficient estimates of both the PRIDIT and the schooling

terms remain significantly positive and the coefficient estimates of the interaction is significantly negative. For the retirement planning variable, the coefficient estimates on both the PRIDIT and the schooling terms also remain significantly positive but the coefficient estimate of the interaction is insignificant.

If the specification of the effects of financial literacy and schooling is limited to only the PRIDIT-schooling interaction term (Panel V in Table 4, equation 1c), the coefficient estimates of the interaction are positive, significant, and fairly substantial for all of the wealth outcomes and for the density of pension contributions and retirement planning.

\section{Instrumental Variable Estimates}

As noted above, omitted variables and/or measurement error can bias measured OLS coefficients, so next we turn to instrumental variable (IV) estimates using the candidate instruments discussed above. Some of the candidate instruments - namely, years of exposure to school vouchers when of school age, AFP marketing efforts, family background, and risk aversion - do not appear to be independent of the second-stage disturbance term but do seem to 
affect wealth accumulation and the density of contribution directly, in addition to indirect effects through schooling and financial literacy. This result suggests that the Hansen J statistic has some power in identifying problematic candidate instruments, and we include all these variables as controls in results to follow (as well as in the OLS estimates discussed above). Our remaining instruments, discussed at the end of this paragraph and listed in Appendix Table B, work quite well. First, they predict both financial literacy and schooling well as is required by the first condition for good instruments. For instance, when financial literacy and schooling enter linearly, the $\mathrm{F}$ tests for excluded instruments respectively are 156.56 and 215.57 (prob $>\mathrm{F}=$ 0.0000 in both cases), the Angrist-Pischke multivariate $\mathrm{F}$ test of excluded instruments respectively are 17.19 and 24.58 (prob $>\mathrm{F}=0.0000$ in both cases), and the Kleibergen-Paap Wald F weak identification test statistic is 15.767, indicating between 5 percent and 10 percent maximal IV relative bias according to the Stock-Yogo weak ID test critical values. Second, they are independent of the second-stage disturbance term as required by the second condition for good instruments. The Hansen J statistic for the overidentification test of all instruments' p values are from 0.26 to 0.92 for the linear specification in equation 1a (see Table 5), indicating that our instruments are independent of the disturbance term in the second-stage relation. ${ }^{25}$ The patterns of significant coefficient estimates are also plausible a priori: positive effects are recorded for having had primary schooling in an urban area and positive self-esteem, and negative effects of unemployment rates when age 16 and negative self-esteem (with some significant deviations from equal weighting for some of the components of esteem). ${ }^{26}$ Interestingly, negative self-esteem is a much more important predictor of both financial literacy and schooling than is positive self-esteem.

When only the PRIDIT financial literacy index is included and instrumented (equation 1a-subvariant 1), the coefficient estimates are positive, significant, substantial, and twice to three times larger than the OLS estimates presented earlier (compare Panel I of Table 5 with Panel I of Table 4). When only schooling is included and instrumented (equation 1a-subvariant 2), the coefficient estimates are positive, significant, substantial, and from 16-84 percent larger than the comparable OLS estimates (Panel II of Table 5 versus Panel II of Table 4). But when we include

\footnotetext{
${ }^{25}$ The p values also are satisfactory for the specification with only the PRIDIT measure of financial literacy in Panel I of Table 5. For the specification with only schooling in Panel II of Table 5 the p values for four of the outcomes are below 0.011. However if the true relation is equation (1a), this relation is actually mis-specified because financial literacy is excluded, which could account for this result.

${ }^{26}$ See Appendix B for a complete set of estimates.
} 
both the instrumented schooling and the PRIDIT financial literacy variables (equation 1a), the schooling effects mostly become statistically insignificant and negative, whereas the PRIDIT effects are positive, significant, substantial and much larger than the OLS results (compare Panel III in Tables 4 and 5; the latter effects are 282-1775 percent larger for the PRIDIT variable) for all of the dependent variables except retirement planning. The effect of financial literacy on retirement planning is no longer statistically significant when we instrument both financial literacy and schooling.

\section{Table 5 here}

This pattern suggests that, if equation (1a) is the true model, OLS coefficient estimates substantially understate the effect of financial literacy on wealth accumulation, due to random measurement error and omitted variable bias. This may be due to omitted factors in the OLS framework that are negatively associated with wealth accumulation but positively correlated with financial literacy. For example, as noted above, over-cautious individuals who invest more in financial literacy may be less successful in accumulating wealth. ${ }^{27}$ If the IV estimates can be interpreted causally, as we argue is appropriate, these estimates mean that financial literacy is a powerful determinant of wealth and pension contributions. Specifically, they imply that a 0.2 standard deviation increase in the PRIDIT financial literacy score could, on average, raise net wealth by $\$ 13,800$, broken down into about a $\$ 5,200$ boost in pension wealth, a $\$ 1,600$ rise in net housing wealth, and a gain of $\$ 6,900$ in other wealth. The same 0.2 standard deviation increase in the PRIDIT financial literacy score would also boost the density of pension contributions by on average of 3 percent and the probability of calculating retirement money by an average of .5 percent. In other words, increased financial literacy can have relatively large payoffs in wealth, particularly pension and other wealth, and less so in terms of housing wealth.

Since the two sets of the HRS questions have also been introduced recently in other international surveys, we assess the marginal impacts of correct responses of the individual questions on each of the six outcomes of interest. Table 6 gives simulated impacts for the "core" as well as the "sophisticated" HRS questions, based on the linear specification of 0.2 standard deviation increases in correct responses to individual questions underlying the PRIDIT estimates. The findings suggest that knowing the correct answers to the HRS "core" questions has a

\footnotetext{
${ }^{27}$ Another example of such positive selection is offered by Finkelstein and McGarry (2006) who show that longterm health care insurance buyers tend to be healthier, which they interpret to indicate that cautious people buy insurance and take good care of their health.
} 
particularly strong impact. It is also of interest that schooling has only a small and insignificant impact when both factors are instrumented. In other words, if the true model is equation (1a) for these outcomes, mis-specifying the relation by leaving out financial literacy (as Table 5, Panel II) leads to rather misleading estimates of the impact of schooling on household wealth accumulations. $^{28}$ Our preferred linear estimates (Table 5, Panel III) for these outcomes suggest that it is financial literacy that actually counts, rather than increasing general schooling attainment. $^{29}$

Table 6 here

Adding a PRIDIT-schooling interaction term in Panel IV of Table 5 (equation 1b) results in coefficient estimates for the interaction terms that are positive for all wealth components (though not for the density of pension contributions or retirement planning) and substantially more precisely estimated than the linear PRIDIT and schooling terms for three of the four wealth components. Indeed the interactions are the only variables that have significantly nonzero coefficient estimates for the wealth components at even the 0.10 level (and for total wealth at the 0.05 level), which suggests a specification that includes only the interaction between PRIDIT and schooling (as in Panel V of Table 5, equation 1c). The diagnostics for such estimates are good: the $\mathrm{F}$ test for excluded instruments ${ }^{30}$ is 109.74 (prob $>\mathrm{F}=0.0000$ ) and the KleibergenPaap rk Wald F weak identification test statistic is 109.74, indicating substantially less than 5 percent maximal IV relative bias according to the Stock-Yogo weak IV test critical values. With regard to the second condition for good instruments, the Hansen $\mathrm{J}$ statistic for the overidentification test of all instruments p values are from 0.39 to 0.95 for the wealth components (last row of Table 5), suggesting that our instruments are independent of the disturbance term in the second-stage relation. ${ }^{31}$ The root mean squared errors are somewhat smaller for the interactive specification in Panel V (equation 1c) than for the linear specifications for other wealth and total wealth (Panel III, equation 1b), but slightly larger for pension wealth,

\footnotetext{
${ }^{28}$ As well as problems with the Hansen's J-test for overidentifying restrictions that suggests that the second condition for good instruments is not satisfied, as noted above.

${ }^{29}$ For other wealth, the schooling coefficient estimate is significant and fairly large but negative (which carries over at the $10 \%$ significance level for total wealth); this result is surprising and may be implausible. We conjecture that this negative schooling coefficient estimate may reflect some interaction with financial literacy that also probably underlies the relatively large coefficient estimate for financial literacy for this outcome.

${ }^{30}$ In the one endogenous variable case, this also is the Angrist-Pischke multivariate F test of excluded instruments.

${ }^{31}$ For the density of contributions this test also is satisfactory with a probability of 0.21 . For the financial planning indicator, however, it is less so with a probability of 0.06 .
} 
household wealth, the density of pension contributions, and retirement planning.

These findings indicate that a case can be made to favor the interactive over the linear specification for other wealth and total wealth, though the estimated effects for the interactive specification are, in any case, substantial for the wealth components and similar to those for the linear model in Panel III of Table 5 discussed above. They imply that a 0.2 standard deviation increase PRIDIT in the interactive format would induce a \$11,600 increase in total net wealth, attributable to a \$5,900 increase in pension wealth, a \$3,600 increase in other wealth, and a $\$ 2,100$ increase in housing wealth. These are somewhat bigger than the implied effects the same PRIDIT change in the linear model for pension wealth (13 percent bigger) and housing wealth (by 28 percent), but substantially smaller for other wealth (48 percent smaller) and somewhat smaller for total wealth (by 16 percent). ${ }^{32}$

Finally, we assess how robust our estimates are to specification changes (results available on request). For example, given intergenerational correlations in schooling (significant correlations of 0.34 with fathers, 0.38 with mothers), including parental schooling as a control in the secondstage could change estimated impacts of respondent schooling attainment. Interestingly, we find no substantial changes in our variables of interest. Similarly, it might be thought that including the family background variables as second-stage controls could make a difference, but again there are no substantial changes in results. Finally, we allow for the possibility that respondent characteristics at the time of the survey, such as current urban residence, current health, marital status, household head/spouse, could enter the second stage; again the relevant coefficient estimates are robust.

\section{Discussion and Implications}

In this paper we use an instrumental variable approach to identify the impact of financial literacy and schooling on wealth accumulation and pension contribution patterns. Prior studies have linked financial literacy and schooling with positive financial outcomes, but they usually do not control for unobserved factors that might shape both financial literacy and schooling, as well as wealth outcomes, nor do they control for possible measurement error in financial literacy and schooling. Using an IV approach (and conditional on our specification assumptions), we have

\footnotetext{
${ }^{32}$ The interactive estimates seem more plausible for other wealth and possibly total net wealth, because the relatively large positive coefficient estimate for financial literacy in the linear case (Table 5, Panel III) may compensate for the substantial significantly negative coefficient estimate for schooling.
} 
isolated the causal effects of financial literacy and schooling on wealth outcomes using plausibly exogenous variation of instruments available in the Chilean Social Protection Survey. Results for a nationally-representative sample of adults indicate that financial literacy and schooling attainment are both positively and significantly correlated with wealth, pension contributions, and retirement planning using OLS, while the IV estimates uncover an even stronger positive impact of financial literacy. They also indicate no significant positive effects of schooling attainment, conditional on financial literacy, in a linear specification, though the effect is positive when interacted with financial literacy.

There are several implications of our findings. First, prior studies using OLS models to estimate the effects of financial literacy and schooling are likely to be misleading due to measurement error and unobserved factors. IV estimates indicate that financial literacy is at least as important, if not more so, than schooling, in explaining variation in household wealth and pension contributions. Second, our improved estimates of the impact of financial literacy are economically meaningful and potentially quite important. Indeed, in our view they are substantial enough to imply that investments in financial literacy could well have high payoffs. Third, our estimates indicate that some components of financial literacy, such as the HRS "core" questions, are particularly important. This insight would not have been gained with the most representations of financial literacy (e.g., percentage correct) used in the previous literature, Fourth, our paper contributes to a growing body of research on the factors influencing peoples' attachment to financial markets. Households that build up more net wealth, particularly via the pension system, may be better able to smooth consumption in retirement and thus enhance risksharing and wellbeing in old age. Our finding that financial literacy enhances peoples' likelihood of contributing to their pension saving suggests that this is a valuable pathway by which improved financial literacy can build household net wealth.

In future work we hope to evaluate in more detail the costs as well as the benefits of enhancing financial literacy levels. Nevertheless, we view as very important the central finding of this paper that individuals, firms, and governments can enhance household wealth and wellbeing by investing in financial literacy. 


\section{References}

Ameriks, John, Andrew Caplin, and John Leahy. 2003. "Wealth Accumulation and the Propensity to Plan.” Quarterly Journal of Economics 68, 1007-1047.

Arenas de Mesa, Alberto, David Bravo, Jere R. Behrman, Olivia S. Mitchell, and Petra E. Todd. With assistance from Andres Otero, Jeremy Skog, Javiera Vasquez, and Viviana Velez-Grajales. 2008. “The Chilean Pension Reform Turns 25: Lessons from the Social Protection Survey.” In Stephen Kay and Tapen Sinha. eds. Lessons from Pension Reform in the Americas, eds. Oxford: OUP 23-58.

Ashenfelter, Orley and Alan Krueger. 1994. "Estimates of the Economic Return to Schooling from a New Sample of Twins," American Economic Review 84:5 (December), 1157-74.

Barsky, Robert, Tom Juster, Miles Kimball, Matt Shapiro, Doug Bernheim, Jon Skinner, and S. Weinberg. 2001. "What Accounts for the Variation in Retirement Wealth among U.S. Households.” American Economic Review 91, 832-857.

Barsky, Robert, Thomas Juster, Miles Kimball, and Matthew Shapiro. 1997. "Preference Parameters and Behavioral Heterogeneity: An Experimental Approach in the Health and Retirement Survey.” NBER Working Paper.

Behrman, Jere R. and Mark R. Rosenzweig. 2002. "Does Increasing Women’s Schooling Raise the Schooling of the Next Generation?” American Economic Review 92:1(March), 323-334.

Behrman, Jere R. and Mark R. Rosenzweig. 2005. "Does Increasing Women’s Schooling Raise the Schooling of the Next Generation? - Reply” American Economic Review 95:5 (December), 1745-1751.

Behrman, Jere R., Mark R. Rosenzweig, and Paul Taubman. 1994. "Endowments and the Allocation of Schooling in the Family and in the Marriage Market: The Twins Experiment." Journal of Political Economy 102:6 (December), 1131-1174.

Bernheim, Doug, Daniel Garrett, and D. Maki. 2001. "Education and Saving: The Long-term Effects of High School Financial Curriculum Mandates”, Journal of Public Economics, 85, 435565.

Bernheim, Douglas, Jonathan Skinner, and Steven Weinberg. 2001. "What Accounts for the Variation in Retirement Wealth among U.S. Households”, American Economic Review, 91(4), 832-857.

Black, Sandra E., Paul J. Devereux, and Kjell G. Salvanes. 2005. “Why the Apple Doesn’t Fall Far: Understanding Intergenerational Transmission of Human Capital," American Economic Review 95:1 (March), 437-449.

Borghans, L., Duckworth, A.L., Heckman, J.J., \& terWeel, B. 2008. The Economics and Psychology of Personality Traits. Journal of Human Resources, 43(4), 972-1059. 
Bouchard T.J. Jr, and M. McGue. 2003. "Genetic and Environmental Influences on Human Psychological Differences." Journal of Neurobiology, 54, 4-45

Bravo, David, Jere Behrman, Olivia S. Mitchell, and Petra Todd. 2004. Análisis y Principales Resultados: Primera Encuesta de Protección Social (Historia Laboral y Seguridad Social, 2002). www.proteccionsocial.cl/english/docs/AnalisisPrincipalesResultadosPrimeraEncuestaProteccionSocial.pdf

Bravo, David, Jere R. Behrman, Olivia S. Mitchell, and Petra Todd. 2006. Encuesta de Protección Social 2004: Presentación General y Principales Resultados. http://www.proteccionsocial.cl/english/docs/Encuesta_Protección_Social\%2020041.pdf

Bravo, David, Sankar Mukhopadhyay, and Petra Todd. 2010. "How Universal School Vouchers Affect Educational and Labor Market Outcomes: Evidence from Chile.” Quantitative Economics (forthcoming).

Brockett, Patrick, Richard A. Derrig, Linda L. Golden, Arnold Levine, Mark Alpert. 2002. "Fraud Classification Using Principal Component Analysis of RIDITs." Journal of Risk and Insurance, 69, 341-371.

Campbell, John. 2006. “Household Finance,” Journal of Finance, 61, 1553-1604.

Cole, Shawn and Gauri Shastry. 2009. "Smart Money: The Effect of Education, Cognitive Ability, and Financial Literacy on Financial Market Participation.” HBS Working Paper 09-071.

Cole, Shawn, Thomas Sampson, and Bilal Zia. 2009. “Money or Knowledge?” HBS working paper 09-117.

Costa, P. T., A. B. Zonderman, R. R. McCrae, J. Cornonihuntley, B. Z. Locke, and H. E. Barbano. 1987. "Longitudinal analyses of psychological well-being in a national sampleStability of mean levels,” Journal of Gerontology 42(1): 50-55.

Csikszentmihalyi, M. and H. Jeremy. 2003. "Happiness in Everyday Life: The Uses of Experience Sampling,” Journal of Happiness 4(2): 185-189.

Dohmen, Thomas, Armin Falk, David Huffman, and Uwe Sunde. 2010a. “Are Risk Aversion and Impatience Related to Cognitive Ability?” American Economic Review 100 (June): 12381260 .

Dohmen, Thomas, Armin Falk, David Huffman, Uwe Sunde, Jürgen Schupp, and Gert G. Wagner. 2010b. "Individual Risk Attitudes: New Evidence from a Large, Representative, Experimentally-Validated Survey." Journal of the European Economic Association. (forthcoming). 
Easterlin, Richard A., 2005. "Is There an 'Iron Law of Happiness?” Department of Economics Working Paper, University of Southern California.

Eckel, Catherine, Cathleen Johnson, and Claude Montmarquette. 2005. "Saving Decisions of the Working Poor: Short- and Long-Term Horizons.” In Research in Experimental Economics. Vol. 10: Field Experiments in Economics, ed. J. P. Carpenter, G. W. Harrison, and J. A. List, 219-60. Amsterdam: Elsevier.

Finkelstein, Amy and K Kathleen McGarry. 2006. "Multiple Dimensions of Private Information: Evidence from the Long-Term Care Insurance Market." American Economic Review, (September) 96(4): 938-958.

Guiso, L., and M. Paiella. 2005. "The Role of Risk Aversion in Predicting Individual Behavior.” Bank of Italy Economic Working Paper No. 546.

Guiso, L., and M. Paiella. 2008. "Risk Aversion, Wealth, and Background Risk.” Journal of the European Economic Association, 6(6): 1109-50.

Hanushek, Erik and Finis Welch, 2006, The Handbook of the Economics of Education, Amsterdam: Elsevier-North-Holland.

Hilgert, M., Hogarth, J., and Beverley, S. 2003. "Household Financial Management: The Connection between Knowledge and Behavior.” Federal Reserve Bulletin Report \#309-322.

Kahneman, Daniel. 1999. “Objective Well-being,” in D. Kahneman, E. Diener, and N. Schwarz (eds.), Well-Being: Foundations of Hedonic Psychology. New York: Russell Sage Foundation, 3-25.

Lykken, D. T. and A. Tellegen. 1996. "Happiness is a Stochastic Phenomenon,” Psychological Science 7(3): 186-189.

Lusardi, Annamaria. 2003. “Planning and Saving for Retirement.” Working Paper, Dartmouth College.

Lusardi, Annamaria, Olivia S. Mitchell, and Vilsa Curto. 2010. "Financial Literacy among the Young: Evidence and Implications for Consumer Policy." Journal of Consumer Affairs. (44, 2): 358-380.

Lusardi, Annamaria and Olivia S. Mitchell. 2007a. "Baby Boomer Retirement Security: The Roles of Planning, Financial Literacy, and Housing Wealth.” Journal of Monetary Economics 54, 205-224.

Lusardi, Annamaria and Olivia S. Mitchell. 2007b. "Financial Literacy and Retirement Planning: New Evidence from the RAND American Life Panel.” NBER Working Paper. 
Lusardi, Annamaria and Olivia S. Mitchell. 2007c. "Financial Literacy and Retirement Preparedness: Evidence and Implications for Financial Education.” Business Economics 42, 3544.

Lusardi, Annamaria and Olivia S. Mitchell. 2008. "Planning and Financial Literacy: How Do Women Fare?” American Economic Review P\&P, 98, 413-417.

Lusardi, Annamaria and Olivia S. Mitchell. 2009. "How Ordinary Consumers Make Complex Economic Decisions: Financial Literacy and Retirement Readiness.” Cambridge, MA: NBER Working Paper.

McCrae, R. R. \& Costa, P. T. (1990). Personality in Adulthood. New York: The Guildford Press.

Mitchell, Olivia S. and James Moore. 1998. "Can Americans Afford to Retire? New Evidence on Retirement Saving Adequacy.” Journal of Risk and Insurance, 65 (3) December: 371-400.

Mitchell, Olivia S., Petra Todd, and David Bravo. 2008. "Learning from the Chilean Experience: The Determinants of Pension Switching." In Annamaria Lusardi, Ed. Overcoming the Saving Slump: Making Financial Education and Saving Programs More Effective. University of Chicago Press, 301-323.

Mruk, C. 2006. Self-Esteem Research, Theory, and Practice: Toward a Positive Psychology of Self-esteem (3rd ed.). New York: Springer

OECD.Nd.“Financial Education.” Directorate for Financial and Enterprise Affairs. www.oecd.org/department/0,3355,en_2649_15251491_1_1_1_1_1,00.html

Plug, Erik. 2004. "Estimating the Effect of Mother's Schooling on Children's Schooling Using a Sample of Adoptees,” American Economic Review 94:1 (March), 358-368.

President's Advisory Committee on Financial Literacy (PACFL). 2008. Annual Report to the President: Executive Summary. $\quad$ www.ustreas.gov/offices/domestic-finance/financial-institution/fineducation/council/exec sum.pdf

Scholz, John Karl, Seshadri, Ananth and Khitatrakun, Surachai. 2006. “Are Americans Saving 'Optimally' for Retirement?” Journal of Political Economy, 114 (August), 607-643.

Srivastava, S., John, O. P., Gosling, S. D., \& Potter, J. 2003. "Development of Personality in Early and Middle Adulthood: Set like Plaster or Persistent Change?” Journal of Personality and Social Psychology, 84, 1041-1053

Staiger, Douglas and James H. Stock. 1997. "Instrumental Variables Regression with Weak Instruments." Econometrica 65:3, 557-586.

Stock, James H. 2010. "The Other Transformation in Econometric Practice: Robust Tools for Inference," Journal of Economic Perspectives 24:2 (Spring), 83-94. 
Stock, James H. and Mark W. Watson. 2007. Introduction to Econometrics, Boston, San Francisco, New York: Peason-Addison Wesley.

Wooldridge, Jeffrey M. 2002. Econometric Analysis of Cross Section and Panel Data, Cambridge, MA: MIT Press. 
Table 1. Summary Statistics for Dependent Variables.

\begin{tabular}{lcccc}
\hline & Mean & St. Dev. & Min. & Max. \\
\hline Wealth components (2006 US\$ 1000s) & & & & \\
Pension Wealth & 38.6 & 87.3 & 0 & 1076.8 \\
Housing Wealth & 22.1 & 43.7 & -223 & 1395.8 \\
Other Wealth & 10.9 & 123 & -553.8 & 11572 \\
Total Wealth & 71.5 & 166.1 & -519.7 & 11985 \\
Pension Density (\%) & 47.7 & 34.8 & 0 & 100 \\
Calculated Retirement Money (\%) & 7.9 & 26.9 & 0 & 100 \\
\hline
\end{tabular}

Note: Calculated from Chilean 2006 Social Protection Survey (EPS) on a sample of 13,054 respondents age 24retirement age (60 for women, 65 for men) for whom key variables (including wealth outcomes, financial literacy, schooling) are available. See text. 
Table 2. Summary Statistics for Right-Side Variables and Candidate Instruments.

\begin{tabular}{|c|c|c|c|c|}
\hline & Mean & St. Dev. & Min. & Max. \\
\hline \multicolumn{5}{|l|}{ Key Right-Side Variables } \\
\hline Financial Literacy PRIDIT Score & 0.6 & 7.7 & -15.3 & 23.3 \\
\hline Schooling Attainment (Grades) & 10.4 & 3.9 & 0 & 20 \\
\hline PRIDIT*Schooling Attainment & 15 & 84.3 & -259.5 & 466.4 \\
\hline \multicolumn{5}{|l|}{ Right-Side Demographic Controls } \\
\hline Age (Years) & 42.7 & 10.6 & 24 & 65 \\
\hline Male (\%) & 51.9 & 50 & 0 & 100 \\
\hline \multicolumn{5}{|l|}{ Candidate First-Stage Instruments } \\
\hline \multicolumn{5}{|l|}{ I. Age-Related Variables } \\
\hline Primary School Urban (\%) & 80.9 & 39.3 & 0 & 100 \\
\hline \multicolumn{5}{|l|}{ School Vouchers } \\
\hline Primary Ages & 2.2 & 3.2 & 0 & 8 \\
\hline Secondary Ages & 1.8 & 1.9 & 0 & 4 \\
\hline Total & 4 & 4.9 & 0 & 12 \\
\hline \multicolumn{5}{|l|}{ AFP Activities at Age 24} \\
\hline Number of Agents $(10 \wedge 3)$ & 6.2 & 6.9 & 0 & 23.7 \\
\hline Marketing Expenditures (P10^9) & 2.2 & 2.7 & 0 & 10.1 \\
\hline No AFP Activities (\%) & 39.2 & 48.8 & 0 & 100 \\
\hline \multicolumn{5}{|l|}{ Macroeconomy at Age 16} \\
\hline Unemployment Rate (\%) & 10.3 & 5.2 & 3 & 23.2 \\
\hline \multicolumn{5}{|l|}{ II. Family Background } \\
\hline Father Schooling Attainment (Grades) & 7.2 & 3.5 & 0 & 20 \\
\hline Mother Schooling Attainment (Grades) & 6.6 & 3.4 & 0 & 20 \\
\hline Poor Economic Background (\%) & 8 & 27.1 & 0 & 100 \\
\hline Respondent Worked < 15 Y of Age (\%) & 6.9 & 25.4 & 0 & 100 \\
\hline \multicolumn{5}{|l|}{ III. Personality Traits } \\
\hline Risk Aversion (\%) & 64.5 & 47.9 & 0 & 100 \\
\hline Positive Self Esteem (Sum) & 16.1 & 2.5 & 5 & 20 \\
\hline Valuable Person & 3.2 & 0.7 & 1 & 4 \\
\hline Number of Good Qualities & 3.2 & 0.6 & 1 & 4 \\
\hline Can Do Well As Others & 3.3 & 0.7 & 1 & 4 \\
\hline Positive Attitude about Self & 3.2 & 0.7 & 1 & 4 \\
\hline Happy with Self & 3.2 & 0.7 & 1 & 4 \\
\hline Negative Self Esteem (Sum) & 10.5 & 2.6 & 5 & 20 \\
\hline Think I am a Failure & 1.8 & 0.7 & 1 & 4 \\
\hline Not Much to be Proud of & 2.1 & 0.9 & 1 & 4 \\
\hline Like More Self Respect & 2.6 & 0.8 & 1 & 4 \\
\hline Sometimes Feel Useless & 2.2 & 0.8 & 1 & 4 \\
\hline Feel Good for Nothing & 1.9 & 0.8 & 1 & 4 \\
\hline \multicolumn{5}{|l|}{ Selected Current Characteristics } \\
\hline Santiago Metropolitan Residence (\%) & 38.4 & 48.6 & 0 & 100 \\
\hline Health Bad (\%) & 6.4 & 24.5 & 0 & 100 \\
\hline Health Good (\%) & 68.7 & 46.4 & 0 & 100 \\
\hline Never Married (\%) & 22.8 & 41.9 & 0 & 100 \\
\hline Now Married (\%) & 65.7 & 47.5 & 0 & 100 \\
\hline Household Head (\%) & 55.5 & 49.7 & 0 & 100 \\
\hline Spouse of Household Head (\%) & 24.3 & 42.9 & 0 & 100 \\
\hline
\end{tabular}

Note: For sample see Table 1. 
Table 3. Financial Literacy Questions: Percent Correct and PRIDIT Weighting Scheme

\begin{tabular}{|c|c|c|c|}
\hline & Question & Correct (\%) & $\begin{array}{l}\text { PRIDIT } \\
\text { weights }\end{array}$ \\
\hline \multicolumn{4}{|c|}{$\begin{array}{l}\text { Concepts of basic economics and finance } \\
\quad \text { Main HRS questions: }\end{array}$} \\
\hline (1) & If the chance of catching an illness is $10 \%$, how many people out of 1000 would get the illness? & $50 \%$ & 0.64 \\
\hline$(2)$ & $\begin{array}{l}\text { If } 5 \text { people share winning lottery tickets and the total prize is } 2 \text { Million pesos, how much would } \\
\text { each receive? }\end{array}$ & $44 \%$ & 0.59 \\
\hline (3) & $\begin{array}{l}\text { Assume that you have } \$ 100 \text { in a savings account and the interest rate you earn on this money is } \\
2 \% \text { a year. If you keep this money in the account for } 5 \text { years, how much would you have after } 5 \\
\text { years? [over } \$ 120 \text {, exactly } \$ 120 \text {, less than } \$ 120 \text { ] }\end{array}$ & $50 \%$ & 0.59 \\
\hline \multicolumn{4}{|c|}{ Additional questions: } \\
\hline (4) & $\begin{array}{l}\text { Assume that you have } \$ 200 \text { in a savings account, and the interest rate that you earn on these } \\
\text { savings is } 10 \% \text { a year. How much would you have in the account after } 2 \text { years? [exact number] }\end{array}$ & $2 \%$ & 0.29 \\
\hline (5) & $\begin{array}{l}\text { Assume that you have } \$ 100 \text { in a savings account and the interest rate that you earn on these } \\
\text { savings is } 1 \% \text { a year. Inflation is } 2 \% \text { a year. After one year, if you withdraw the money from } \\
\text { the savings account you could buy more/less/the same? }\end{array}$ & $26 \%$ & 0.42 \\
\hline (6) & $\begin{array}{l}\mathrm{T} / \mathrm{F} \text { : Buying shares in one company is less risky than buying shares from many different } \\
\text { companies with the same money. }\end{array}$ & $46 \%$ & 0.44 \\
\hline \multicolumn{4}{|c|}{ Knowledge of benefit rules and institutions } \\
\hline (7) & $\begin{array}{l}\text { Do you knows what percentage of income is (has been or would be) deducted monthly for } \\
\text { pension system contributions? [yes/no] }\end{array}$ & $37 \%$ & 0.54 \\
\hline$(8)$ & Do you know the legal retirement age for women? [60] & $79 \%$ & 0.44 \\
\hline (9) & Do you know the legal retirement age for men? [65] & $84 \%$ & 0.41 \\
\hline (10) & $\begin{array}{l}\text { Do you know how to calculate pensions in the AFP? [yes, by balance of individual account and } \\
\text { other elements such as age of retirement] }\end{array}$ & $10 \%$ & 0.37 \\
\hline$(11)$ & $\begin{array}{l}\text { Do you know there is a minimum state guaranteed old age pension for people aged } 65 \text { and } \\
\text { over? [yes/no] }\end{array}$ & $53 \%$ & 0.42 \\
\hline$(12)$ & Have you heard of the Voluntary Pension Savings system introduced in 2002? [yes/no] & $55 \%$ & 0.58 \\
\hline
\end{tabular}

Note: For sample see Table 1. The PRIDIT financial literacy score is calculated using the 12 financial literacy questions in the 2006 EPS. Column 1 lists the $\%$ of people that answered the question correctly; Column 2 provides PRIDIT weights for each question (see text). 
Table 4. OLS Models of Wealth and Pension Density: PRIDIT Alone, Schooling Alone, and Both, Plus Interactions

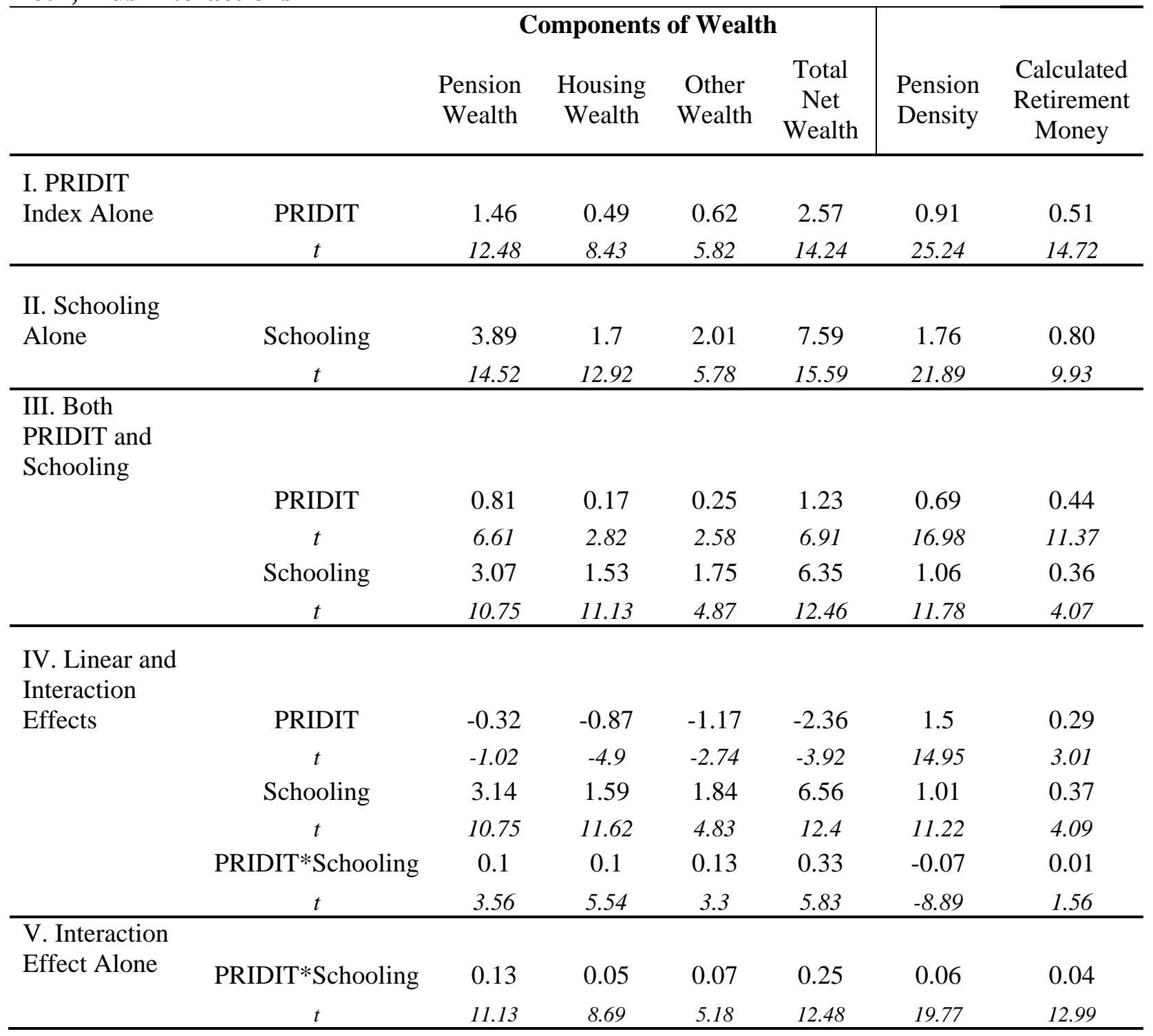

Notes: For sample size see Table 1. A complete set of coefficient estimates is provided in Appendix A. Pension density is included in the estimates as proportion between 0 and 1 but the coefficient estimate is multiplied by 100 in this table to be of the same magnitude as the other coefficient estimates. Other control variables include age, age squared, male, years of exposure to school vouchers when of school age, AFP marketing efforts, family background, and risk aversion. " $t$ ” refers to t-statistic. 
Table 5. IV Models of Wealth and Pension Density: PRIDIT Alone, Schooling Alone, and Both, Plus Interactions

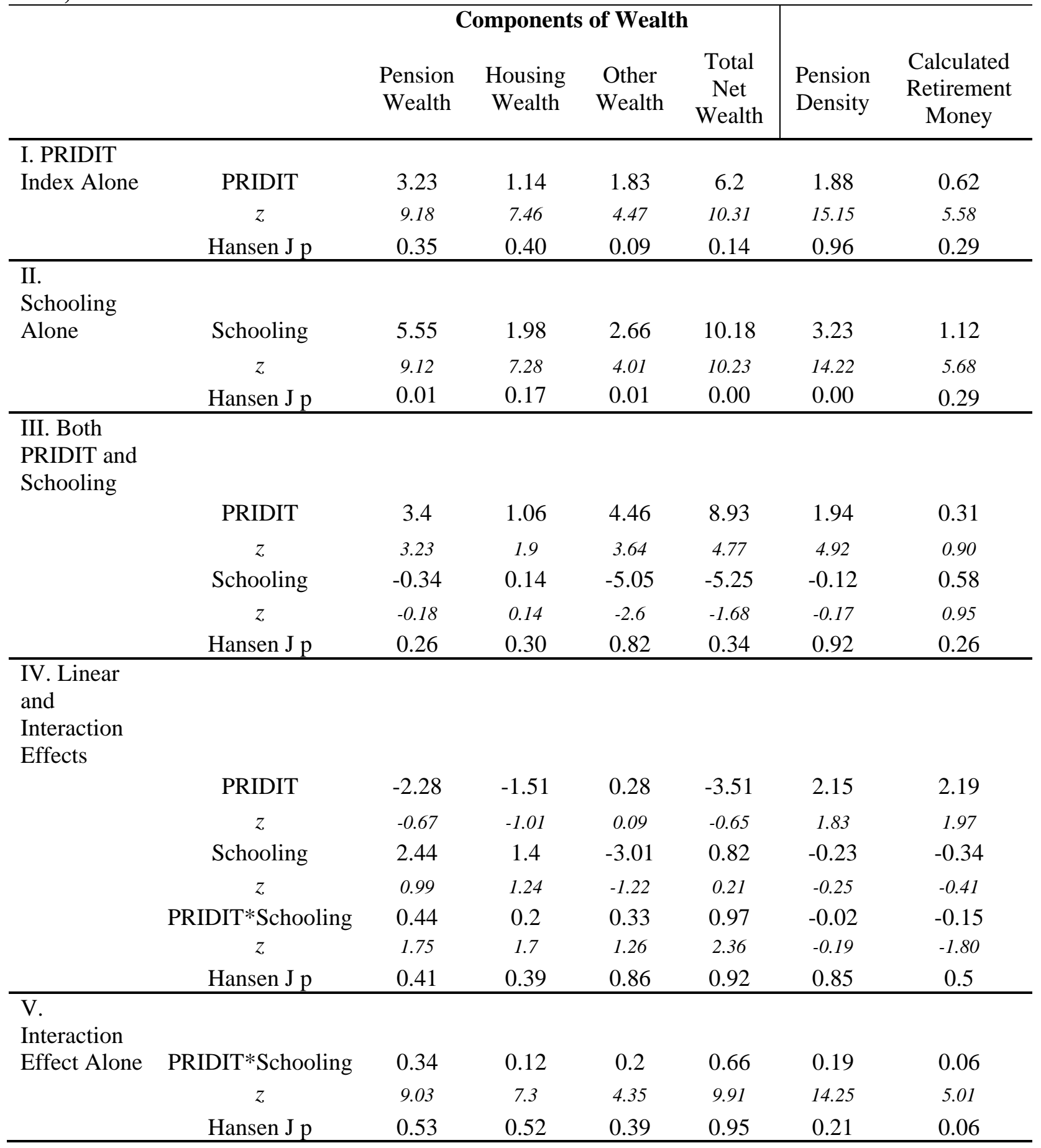

Notes: For sample size see Table 1. A complete set of coefficient estimates is provided in Appendix B. Pension density is included in the estimates as proportion between 0 and 1 but the coefficient estimate is multiplied by 100 in this table to be of the same magnitude as the other coefficient estimates. Other control variables include age, age squared, male, years of exposure to school vouchers when of school age, AFP marketing efforts, family background, and risk aversion. " $z$ ” refers to z-statistic; see text. 
Table 6. Predicted Change in Measured Outcomes for Correct Answer to Financial Literacy Question

\begin{tabular}{|c|c|c|c|c|c|}
\hline $\begin{array}{l}\text { Pension } \\
\text { Wealth } \\
\text { (\$000) }\end{array}$ & $\begin{array}{l}\text { Housing } \\
\text { Wealth } \\
(\$ 000)\end{array}$ & $\begin{array}{l}\text { Other } \\
\text { Wealth } \\
(\$ 000)\end{array}$ & $\begin{array}{c}\text { Total } \\
\text { Net } \\
\text { Wealth } \\
(\$ 000) \\
\end{array}$ & $\begin{array}{l}\text { Pension } \\
\text { Density } \\
\text { (\% pts) }\end{array}$ & $\begin{array}{c}\text { Calculated } \\
\text { Retirement } \\
\text { Money } \\
(\% \text { pts) }\end{array}$ \\
\hline
\end{tabular}

\section{Core HRS Questions:}

If the chance of catching an

illness is $10 \%$, how many

people out of 1000 would

$1.2 \quad 0.4$

1.6

3.1

0.7

0.11

get the illness?

If 5 people share winning

(2) lottery tickets and the total prize is 2 Million pesos, how

1.1

0.4

1.5

2.9

0.6

0.10

much would each receive?

Assume that you have $\$ 100$

in a savings account and the interest rate you earn on this

(3) money is $2 \%$ a year. If you keep this money in the

$\begin{array}{llllll}1.1 & 0.3 & 1.4 & 2.9 & 0.6 & 0.10\end{array}$
account for 5 years, how much would you have after 5 years?

\section{Sophisticated HRS:}

Assume that you have $\$ 200$ in a savings account, and the interest rate that you earn on these savings is $10 \%$ a year.
0.6
0.2
0.7
1.5
0.3
0.05

How much would you have in the account after 2 years?

Assume that you have $\$ 100$ in a savings account and the interest rate that you earn on these savings is $1 \%$ a year.

(5) Inflation is $2 \%$ a year. After one year, if you withdraw 0.8 0.2 1.0 2.1 0.4 0.07 the money from the savings account you could buy more/less/the same?

$\mathrm{T} / \mathrm{F}$ : Buying shares in one company is less risky than

(6) buying shares from many different companies with the $\begin{array}{ll}0.8 & 0.3\end{array}$ 1.1 2.1 0.5 0.07 same money.

Note: The table presents simulated marginal effects of increasing the probability of answering each question correctly by a quarter standard deviation (Table 2 indicates mean responses) on outcomes, holding population responses to other questions constant. 


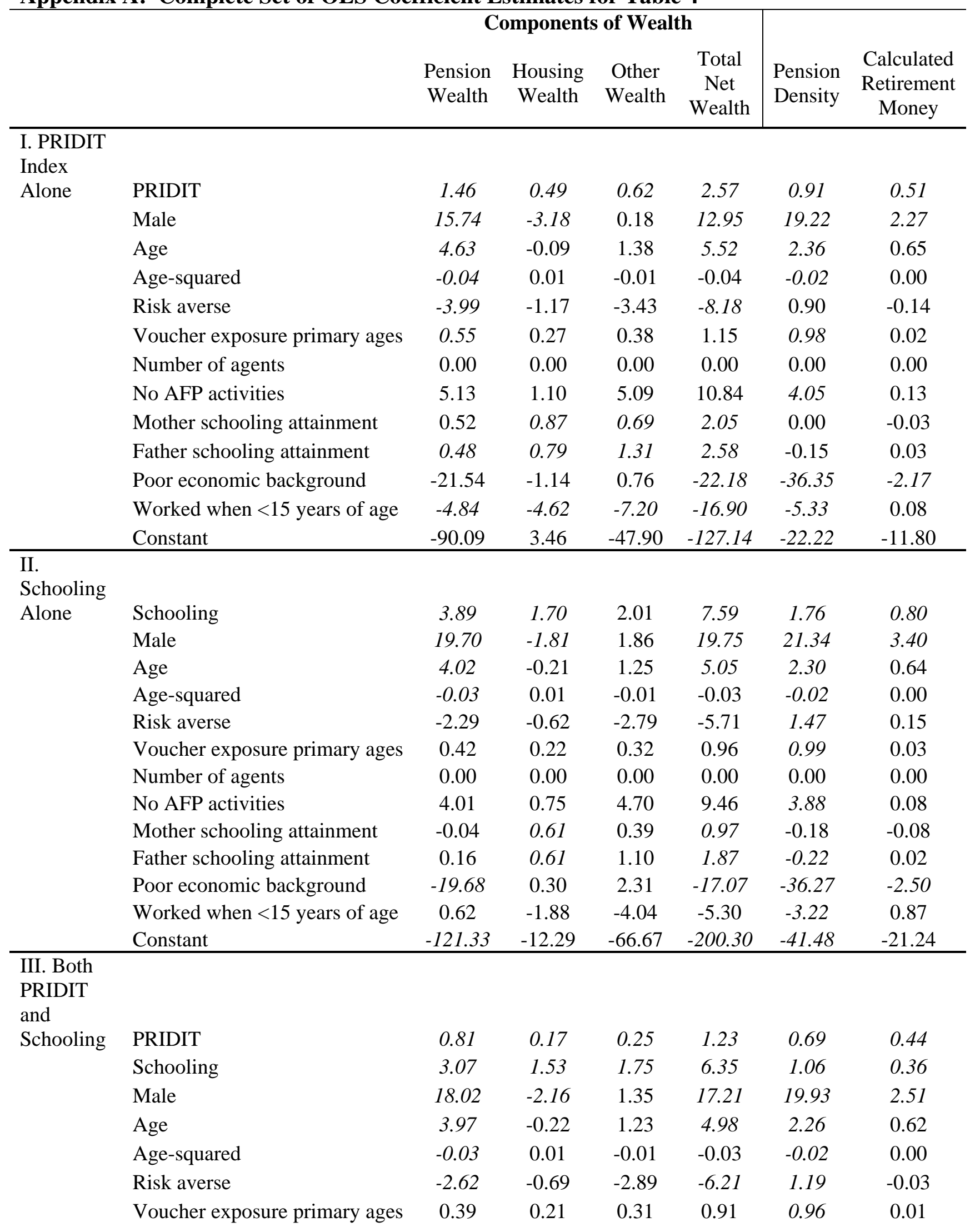




\begin{tabular}{|c|c|c|c|c|c|c|c|}
\hline & Number of agents & 0.00 & 0.00 & 0.00 & 0.00 & 0.00 & 0.00 \\
\hline & No AFP activities & 3.93 & 0.74 & 4.68 & 9.35 & 3.82 & 0.04 \\
\hline & Mother schooling attainment & -0.05 & 0.61 & 0.39 & 0.94 & -0.19 & -0.09 \\
\hline & Father schooling attainment & 0.09 & 0.60 & 1.08 & 1.77 & -0.28 & -0.01 \\
\hline & Poor economic background & -18.28 & 0.59 & 2.74 & -14.95 & -35.09 & -1.75 \\
\hline & Worked when $<15$ years of age & 0.39 & -1.93 & -4.11 & -5.65 & -3.42 & 0.73 \\
\hline & Constant & -109.59 & -9.81 & -63.05 & -182.45 & -31.53 & -14.97 \\
\hline \multirow{16}{*}{$\begin{array}{l}\text { IV. Linear } \\
\text { and } \\
\text { Interaction } \\
\text { Effects }\end{array}$} & & & & & & & \\
\hline & PRIDIT & -0.32 & -0.87 & -1.17 & -2.36 & 1.50 & 0.29 \\
\hline & Schooling & 3.14 & 1.59 & 1.84 & 6.56 & 1.01 & 0.37 \\
\hline & PRIDIT*Schooling & 0.10 & 0.10 & 0.13 & 0.33 & -0.07 & 0.01 \\
\hline & Male & 17.98 & -2.21 & 1.29 & 17.05 & 19.96 & 2.50 \\
\hline & Age & 3.94 & -0.25 & 1.19 & 4.88 & 2.28 & 0.62 \\
\hline & Age-squared & -0.03 & 0.01 & -0.01 & -0.03 & -0.02 & 0.00 \\
\hline & Risk averse & -2.25 & -0.35 & -2.42 & -5.02 & 0.92 & 0.02 \\
\hline & Voucher exposure primary ages & 0.35 & 0.18 & 0.27 & 0.79 & 0.99 & 0.00 \\
\hline & Number of agents & 0.00 & 0.00 & 0.00 & 0.00 & 0.00 & 0.00 \\
\hline & No AFP activities & 4.13 & 0.92 & 4.93 & 9.97 & 3.68 & 0.07 \\
\hline & Mother schooling attainment & -0.10 & 0.56 & 0.33 & 0.79 & -0.16 & -0.10 \\
\hline & Father schooling attainment & 0.05 & 0.56 & 1.03 & 1.63 & -0.24 & -0.02 \\
\hline & Poor economic background & -19.51 & -0.54 & 1.16 & -18.89 & -34.18 & -1.91 \\
\hline & Worked when $<15$ years of age & 0.42 & -1.90 & -4.07 & -5.54 & -3.44 & 0.73 \\
\hline & Constant & -109.92 & -10.12 & -63.48 & -183.52 & -31.28 & -15.02 \\
\hline \multirow{14}{*}{$\begin{array}{l}\text { V. } \\
\text { Interaction } \\
\text { Effect } \\
\text { Alone }\end{array}$} & & & & & & & \\
\hline & PRIDIT*Schooling & 0.13 & 0.05 & 0.07 & 0.25 & 0.06 & 0.04 \\
\hline & Male & 15.97 & -3.33 & -0.04 & 12.60 & 19.59 & 2.32 \\
\hline & Age & 4.22 & -0.11 & 1.35 & 5.45 & 2.38 & 0.65 \\
\hline & Age-squared & -0.04 & 0.01 & -0.01 & -0.04 & -0.02 & 0.00 \\
\hline & Risk averse & -3.13 & -1.00 & -3.22 & -7.35 & 1.10 & 0.01 \\
\hline & Voucher exposure primary ages & 0.47 & 0.25 & 0.35 & 1.06 & 1.00 & 0.01 \\
\hline & Number of agents & 0.00 & 0.00 & 0.00 & 0.00 & 0.00 & 0.00 \\
\hline & No AFP activities & 4.95 & 1.18 & 5.18 & 11.31 & 4.30 & 0.24 \\
\hline & Mother schooling attainment & 0.46 & 0.84 & 0.64 & 1.94 & 0.03 & -0.03 \\
\hline & Father schooling attainment & 0.46 & 0.76 & 1.26 & 2.47 & -0.10 & 0.03 \\
\hline & Poor economic background & -23.71 & -1.58 & 0.26 & -25.02 & -37.96 & -2.90 \\
\hline & Worked when $<15$ years of age & -5.33 & -4.55 & -7.07 & -16.95 & -5.81 & -0.05 \\
\hline & Constant & -82.94 & 3.99 & -47.08 & -126.02 & -23.91 & -12.08 \\
\hline
\end{tabular}

Note: *italics indicate significance at $5 \%$ level or better. See also Table 4. 
Appendix B: Complete Set of IV Estimates for Table 5; first-stage estimates and diagnostics, and second-stage estimates and diagnostics*

\begin{tabular}{|c|c|c|c|c|c|}
\hline \multicolumn{4}{|c|}{ Components of Wealth } & \multirow[b]{2}{*}{$\begin{array}{l}\text { Pension } \\
\text { Density }\end{array}$} & \multirow[b]{2}{*}{$\begin{array}{c}\text { Calculated } \\
\text { Retirement } \\
\text { Money }\end{array}$} \\
\hline $\begin{array}{l}\text { Pension } \\
\text { Wealth }\end{array}$ & $\begin{array}{c}\text { Housing } \\
\text { Wealth }\end{array}$ & $\begin{array}{l}\text { Other } \\
\text { Wealth }\end{array}$ & $\begin{array}{c}\text { Total } \\
\text { Net } \\
\text { Wealth }\end{array}$ & & \\
\hline
\end{tabular}

\begin{tabular}{|c|c|c|c|c|c|c|c|}
\hline $\begin{array}{l}\text { I. PRIDIT } \\
\text { Index }\end{array}$ & & & & & & & \\
\hline Alone & PRIDIT & 3.23 & 1.14 & 1.83 & 6.20 & 1.88 & 0.62 \\
\hline & Male & 12.66 & -4.30 & -1.91 & 6.44 & 17.54 & 2.09 \\
\hline & Age & 4.32 & -0.22 & 1.12 & 5.22 & 2.19 & 0.63 \\
\hline & Age-squared & -0.04 & 0.01 & 0.00 & -0.04 & -0.02 & 0.00 \\
\hline & Risk averse & -4.19 & -1.23 & -3.56 & -8.99 & 0.79 & -0.15 \\
\hline & Voucher exposure primary ages & 0.38 & 0.20 & 0.27 & 0.86 & 0.89 & 0.01 \\
\hline & Number of agents & 0.00 & 0.00 & 0.00 & 0.00 & 0.00 & 0.00 \\
\hline & No AFP activities & 4.43 & 0.83 & 4.57 & 9.83 & 3.66 & 0.09 \\
\hline & Mother schooling attainment & 0.08 & 0.71 & 0.38 & 1.18 & -0.25 & -0.05 \\
\hline & Father schooling attainment & 0.01 & 0.62 & 0.99 & 1.62 & -0.40 & 0.01 \\
\hline & Poor economic background & -15.08 & 1.17 & 5.18 & -8.72 & -32.83 & -1.79 \\
\hline & Worked when $<15$ years of age & -1.50 & -3.67 & -5.01 & -10.17 & -3.51 & 0.28 \\
\hline & Constant & -77.73 & 8.15 & -38.71 & -108.28 & -15.48 & -11.08 \\
\hline & Hansen J p & 0.35 & 0.40 & 0.09 & 0.14 & 0.96 & 0.29 \\
\hline $\begin{array}{l}\text { II. } \\
\text { Schooling }\end{array}$ & & & & & & & \\
\hline Alone & Schooling & 5.55 & 1.98 & 2.66 & 10.18 & 3.23 & 1.12 \\
\hline & Male & 19.95 & -1.73 & 2.08 & 20.30 & 21.78 & 3.50 \\
\hline & Age & 4.22 & -0.25 & 1.12 & 5.09 & 2.13 & 0.61 \\
\hline & Age-squared & -0.03 & 0.01 & 0.00 & -0.03 & -0.02 & 0.00 \\
\hline & Risk averse & -2.21 & -0.53 & -2.58 & -5.32 & 1.95 & 0.24 \\
\hline & Voucher exposure primary ages & 0.38 & 0.20 & 0.29 & 0.88 & 0.89 & 0.01 \\
\hline & Number of agents & 0.00 & 0.00 & 0.00 & 0.00 & 0.00 & 0.00 \\
\hline & No AFP activities & 3.98 & 0.66 & 4.47 & 9.11 & 3.40 & -0.02 \\
\hline & Mother schooling attainment & -0.38 & 0.55 & 0.24 & 0.41 & -0.51 & -0.16 \\
\hline & Father schooling attainment & -0.14 & 0.56 & 0.99 & 1.42 & -0.49 & -0.03 \\
\hline & Poor economic background & -16.27 & 0.81 & 3.57 & -11.90 & -33.51 & -1.89 \\
\hline & Worked when $<15$ years of age & 4.51 & -1.50 & -2.67 & 0.34 & 0.00 & 1.57 \\
\hline & Constant & -140.83 & -14.26 & -70.93 & -226.01 & -52.21 & -23.58 \\
\hline & Hansen $\mathrm{J}$ p & 0.01 & 0.17 & 0.01 & 0.00 & 0.00 & 0.29 \\
\hline $\begin{array}{l}\text { III. Both } \\
\text { PRIDIT } \\
\text { and }\end{array}$ & & & & & & & \\
\hline Schooling & PRIDIT & 3.40 & 1.06 & 4.46 & 8.93 & 1.94 & 0.31 \\
\hline & Schooling & -0.34 & 0.14 & -5.05 & -5.25 & -0.12 & 0.58 \\
\hline & Male & 12.25 & -4.13 & -8.01 & 0.11 & 17.39 & 2.79 \\
\hline
\end{tabular}




\begin{tabular}{|c|c|c|c|c|c|c|c|}
\hline & Age & 4.33 & -0.22 & 1.26 & 5.36 & 2.19 & 0.62 \\
\hline & Age-squared & -0.04 & 0.01 & -0.01 & -0.04 & -0.02 & 0.00 \\
\hline & Risk averse & -4.31 & -1.18 & -5.33 & -10.83 & 0.75 & 0.05 \\
\hline & Voucher exposure primary ages & 0.39 & 0.20 & 0.30 & 0.89 & 0.89 & 0.01 \\
\hline & Number of agents & 0.00 & 0.00 & 0.00 & 0.00 & 0.00 & 0.00 \\
\hline & No AFP activities & 4.46 & 0.82 & 5.11 & 10.38 & 3.67 & 0.02 \\
\hline & Mother schooling attainment & 0.11 & 0.70 & 0.88 & 1.69 & -0.23 & -0.11 \\
\hline & Father schooling attainment & 0.03 & 0.61 & 1.21 & 1.85 & -0.40 & -0.02 \\
\hline & Poor economic background & -15.09 & 1.18 & 5.12 & -8.79 & -32.84 & -1.78 \\
\hline & Worked when $<15$ years of age & -1.90 & -3.50 & -11.08 & -16.47 & -3.66 & 0.98 \\
\hline & Constant & -74.03 & 6.58 & 16.60 & -50.84 & -14.12 & -17.47 \\
\hline & Hansen J p & 0.26 & 0.30 & 0.82 & 0.34 & 0.92 & 0.26 \\
\hline \multirow[t]{17}{*}{$\begin{array}{l}\text { IV. Linear } \\
\text { and } \\
\text { Interaction } \\
\text { Effects }\end{array}$} & & & & & & & \\
\hline & PRIDIT & -2.28 & -1.51 & 0.28 & -3.51 & 2.15 & 2.19 \\
\hline & Schooling & 2.44 & 1.40 & -3.01 & 0.82 & -0.23 & -0.34 \\
\hline & PRIDIT*Schooling & 0.44 & 0.20 & 0.33 & 0.97 & -0.02 & -0.15 \\
\hline & Male & 14.32 & -3.19 & -6.48 & 4.65 & 17.31 & 2.11 \\
\hline & Age & 4.06 & -0.34 & 1.06 & 4.79 & 2.20 & 0.70 \\
\hline & Age-squared & -0.04 & 0.01 & -0.01 & -0.03 & -0.02 & -0.01 \\
\hline & Risk averse & -1.91 & -0.09 & -3.57 & -5.57 & 0.66 & -0.75 \\
\hline & Voucher exposure primary ages & 0.17 & 0.11 & 0.14 & 0.42 & 0.90 & 0.08 \\
\hline & Number of agents & 0.00 & 0.00 & 0.00 & 0.00 & 0.00 & 0.00 \\
\hline & No AFP activities & 4.88 & 1.01 & 5.42 & 11.30 & 3.66 & -0.12 \\
\hline & Mother schooling attainment & -0.44 & 0.45 & 0.47 & 0.48 & -0.21 & 0.07 \\
\hline & Father schooling attainment & -0.38 & 0.43 & 0.91 & 0.96 & -0.38 & 0.12 \\
\hline & Poor economic background & -18.83 & -0.52 & 2.36 & -17.00 & -32.70 & -0.54 \\
\hline & Worked when $<15$ years of age & 2.09 & -1.69 & -8.14 & -7.74 & -3.80 & -0.34 \\
\hline & Constant & -99.93 & -5.14 & -2.47 & -107.54 & -13.18 & -8.88 \\
\hline & Hansen J p & 0.41 & 0.39 & 0.86 & 0.92 & 0.85 & 0.50 \\
\hline \multirow{11}{*}{$\begin{array}{l}\text { V. } \\
\text { Interaction } \\
\text { Effect } \\
\text { Alone }\end{array}$} & & & & & & & \\
\hline & PRIDIT*Schooling & 0.34 & 0.12 & 0.20 & 0.66 & 0.19 & 0.06 \\
\hline & Male & 11.71 & -4.64 & -2.67 & 4.40 & 17.11 & 2.03 \\
\hline & Age & 4.18 & -0.26 & 1.01 & 4.93 & 2.12 & 0.62 \\
\hline & Age-squared & -0.04 & 0.01 & 0.00 & -0.04 & -0.02 & 0.00 \\
\hline & Risk averse & -3.11 & -0.85 & -2.92 & -6.88 & 1.41 & 0.04 \\
\hline & Voucher exposure primary ages & 0.23 & 0.15 & 0.17 & 0.55 & 0.81 & -0.01 \\
\hline & Number of agents & 0.00 & 0.00 & 0.00 & 0.00 & 0.00 & 0.00 \\
\hline & No AFP activities & 4.97 & 1.02 & 4.86 & 10.85 & 3.99 & 0.20 \\
\hline & Mother schooling attainment & -0.13 & 0.64 & 0.23 & 0.74 & -0.35 & -0.07 \\
\hline & Father schooling attainment & -0.20 & 0.54 & 0.83 & 1.17 & -0.51 & -0.01 \\
\hline
\end{tabular}




\begin{tabular}{lcccccc} 
Poor economic background & -18.00 & 0.16 & 3.83 & -14.01 & -34.69 & -2.51 \\
Worked when $<15$ years of age & -1.02 & -3.49 & -4.51 & -9.03 & -3.35 & 0.24 \\
Constant & -74.43 & 9.35 & -35.96 & -101.04 & -14.03 & -10.94 \\
Hansen J p & 0.53 & 0.52 & 0.39 & 0.95 & 0.21 & 0.06 \\
\hline
\end{tabular}

Notes: also Table 4.

Source: Authors' computations. 


\section{Appendix Table B. First Stage Estimates}

\begin{tabular}{|c|c|c|c|}
\hline & PRIDIT Index & Schooling & PRIDIT*Schooling \\
\hline Male & 1.77 & -0.25 & 19.87 \\
\hline Age & 0.07 & 0.09 & 1.22 \\
\hline Age-squared & 0.00 & 0.00 & -0.01 \\
\hline Risk averse & 0.17 & -0.25 & -1.65 \\
\hline Voucher exposure primary ages & -0.04 & 0.03 & 0.13 \\
\hline Number of agents & 0.00 & 0.00 & 0.00 \\
\hline No AFP activities & 0.04 & 0.18 & -1.28 \\
\hline Mother schooling attainment & 0.17 & 0.18 & 2.31 \\
\hline Father schooling attainment & 0.19 & 0.13 & 2.50 \\
\hline Poor economic background & -2.96 & -1.51 & -20.16 \\
\hline Worked when $<15$ years of age & -1.41 & -1.90 & -15.13 \\
\hline Primary school urban & 2.92 & 2.32 & 20.18 \\
\hline Unemployment rate at age 16 & -6.21 & -1.32 & -58.02 \\
\hline Think I am a Failure & 0.08 & 0.12 & 1.87 \\
\hline Can Do Well As Others & 0.46 & 0.19 & 4.05 \\
\hline Positive Attitude about Self & 0.28 & 0.16 & 1.91 \\
\hline Like More Self Respect & 0.04 & -0.14 & -2.06 \\
\hline Postive Self Esteem (Sum) & 0.10 & 0.01 & 1.36 \\
\hline Negative Self Esteem (Sum) & -0.58 & -0.24 & -6.04 \\
\hline Constant & -3.25 & 8.11 & -31.71 \\
\hline F test stat: & 156.56 & 215.57 & 109.72 \\
\hline \multicolumn{4}{|l|}{ Angrist-Pischke multivariate F stat: } \\
\hline III. Both PRIDIT and Schooling & 17.19 & 24.58 & \\
\hline IV. Linear and Interaction Effects & 2.32 & 19.05 & 3.16 \\
\hline \multicolumn{4}{|l|}{ Kleibergen-Paap Wald F stat: } \\
\hline III. Both PRIDIT and Schooling & 15.77 & & \\
\hline IV. Linear and Interaction Effects & 9.43 & & \\
\hline
\end{tabular}

Note: *italics indicate significance at $5 \%$ level or better

Source: Authors' computations. 